\title{
Jesus and the Bulldozer: Religion, Suburbanization, and Urban Renewal in a New Jersey Camp Meeting Community
}

\section{By Samuel Avery-Quinn, PhD}

DOI: https://doi.org/10.14713/njis.v7i2.249

The history of suburbanization in New Jersey is a well-established topic in the scholarly literature. Since the middle decades of the nineteenth century, the state's northeastern and southwestern areas have become dense with suburban communities tied, culturally and economically, to New York City or Philadelphia. By the early twentieth century, these areas were a mix of middle-class white enclaves, Black towns, immigrant and working-class communities, agricultural hamlets, and industrial suburbs. However, in the late nineteenth century, some suburbs emerged as religious retreats. This article explores how suburbanization and, by the 1960s, urban renewal, transformed the Gloucester County borough of Pitman's landscape. Founded in 1871 as a Methodist camp meeting resort, the history of Pitman demonstrates ways that religion complemented suburbanization, and suburbanization, amid religious decline and secularization, reshaped the religious landscape of one South Jersey community.

In April 1975, Helen Wood leaned back in her chair and smiled. Standing across the room, a reporter snapped her photo. ${ }^{1}$ Wood may have lost track of how many reporters had visited her neighborhood of Pitman Grove since officials for the small Gloucester County borough of Pitman launched a plan to bulldoze what was once South Jersey's most popular Methodist camp meeting. "Billy Sunday used to preach here," she said, pointing to the auditorium outside her parlor window, "all the great evangelists used to come down here." When the reporter asked what Pitman would lose in urban renewal, Wood paused. "You know we used to have a boardwalk by Alcyon Lake?

\footnotetext{
1 “Condemnation Nears Tabernacle," The Philadelphia Inquirer, April 9, 1975.
} 
And an amusement park? People from Philadelphia would come on the trains every summer," she said. "All that's left is the Grove. I'd like the Grove to stay the way it is. Don't people like to preserve their beginnings?"

When Helen Wood posed that question, the Borough of Pitman was far removed from those Methodist beginnings. In 1905, local businessmen established a two-square-mile secular borough surrounding the camp meeting. Real estate speculators soon filled in the borough's contours with idyllic tracts of home sites they advertised as affordable suburban living, convenient by railroad to Camden and Philadelphia. Crowds attending the camp meeting's summer revivals began to thin in the 1910s, and, by the 1930s, the camp meeting's fortunes declined precipitously. In the 1950s, borough officials claimed the camp meeting was a blighted area. Proposals to demolish the grounds threatened Pitman Grove through the early 1970s. However, in 1976, the State of New Jersey intervened on behalf of Wood and her neighbors, supporting Pitman Grove's listing on the National Register of Historic Places. The Grove's long road to preservation was shaped by years of conflicts over power and municipal policies. As scholars advocating a new suburban history argue, such conflicts were widespread in the twentieth-century transformation of metropolitan America. ${ }^{2}$ Changing federal housing and transportation infrastructure policies; the proliferation of municipalities responsible for governing land use, local schools, and taxation; stark divisions of metropolitan areas by class and race; economic disinvestment in central cities; the rapid growth of automobile ownership; and dramatic population shifts defined the suburban landscape of twentieth-century America. ${ }^{3}$

\footnotetext{
${ }^{2}$ Kevin Kruse and Thomas Sugrue, The New Suburban History (University of Chicago Press, 2006).

${ }^{3}$ Scholarly literature on suburbanization in America is vast. For historical overviews, see Jon Teaford, The American Suburb (New York: Routledge, 2007); Becky Nicolaides and Andrew Wiese, eds., The Suburb Reader (New York: Routledge, 2006); Delores Hayden, Building Suburbia: Greenfields and Urban Growth, $1820-2000$ (New York: Pantheon Books, 2003); Robert Fishman, Bourgeois Utopias: The Rise and Fall of Suburbia (New York: Basic Books, 1987); Kenneth T. Jackson, Crabgrass Frontier: The Suburbanization of the United States (New York: Oxford University Press, 1985).
} 


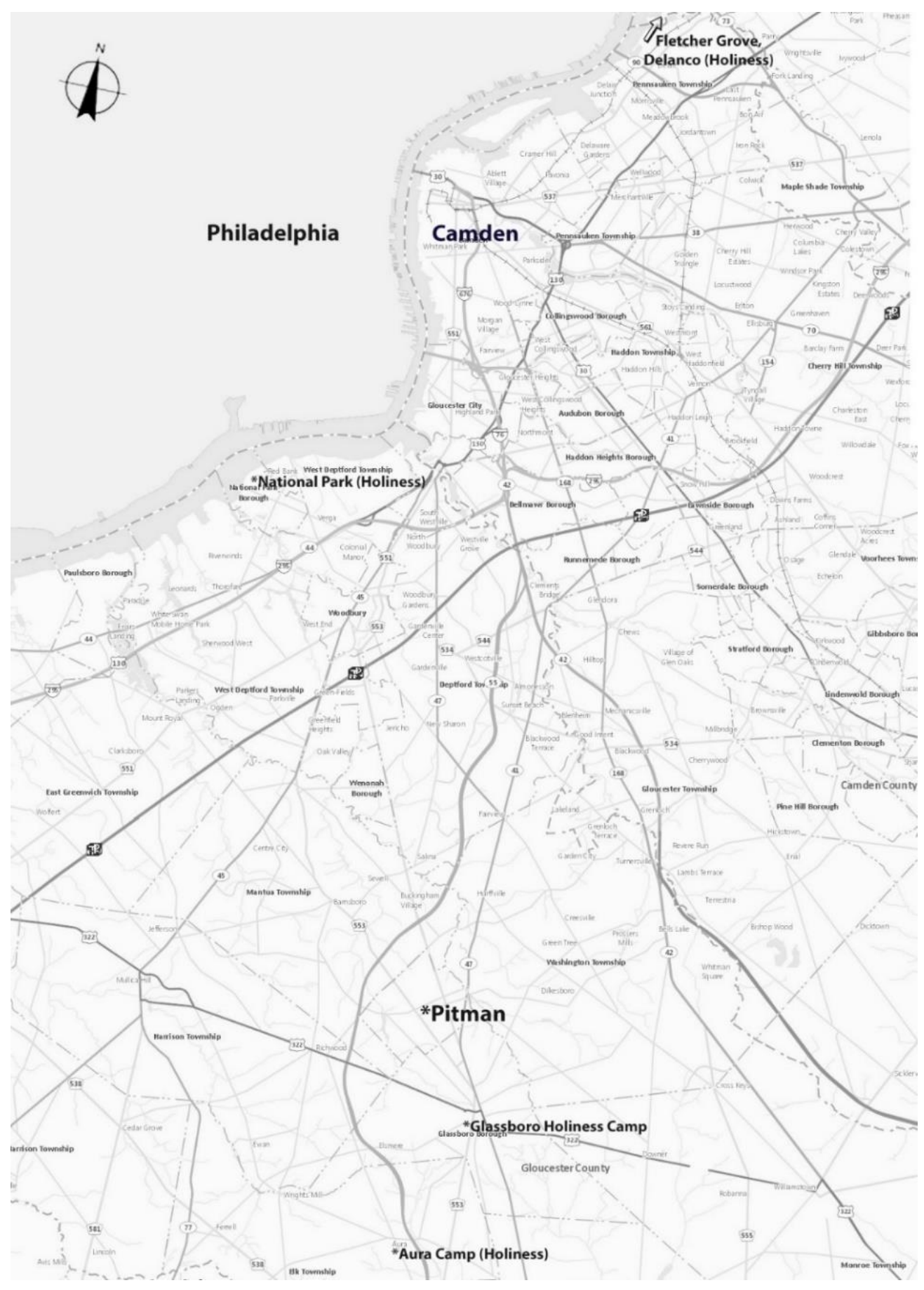

Map of Southern New Jersey below Philadelphia. Labels indicate the Borough of Pitman and area holiness camp meetings. ${ }^{4}$

\footnotetext{
${ }^{4}$ ArcGIS Online (C ESRI, http://www.arcgis.com. Map not to scale.
} 
However, Pitman's origins as a Methodist camp meeting resort make the borough a unique intersection of religion, suburbanization, and town planning. The forces of suburbanization that buffeted Pitman Grove had roots in early-nineteenth-century cities reconfigured by industrialization, growing numbers of white-collar jobs, new transportation technologies, and the changing tastes of America's emerging middle class. ${ }^{5}$ Members of the white urban middle class were fearful of the consequences of industrialization and immigration and, influenced by domestic advice manuals, regarded their homes as bastions from the ills of the city. Land companies outside the city beckoned them with a new suburban ideal. ${ }^{6}$ A short commute from the city, lots for singlefamily homes served both as emplacements of women's domesticity and affirmations of men's middle-class status as homeowners. By the 1870s, streetcar build-outs, satellite suburbs, and picturesque enclaves of upper-class estates and middle-class homes fringed American cities. These suburban matrices enveloped industrial sites dotted with worker housing, once rural Black towns, immigrant agricultural settlements, and, in wealthier suburbs, predominantly Black service enclaves. $^{7}$

\footnotetext{
${ }^{5}$ For middle-class formation in the nineteenth-century city, see John Hepp, IV, The Middle-Class City: Transforming Space and Time in Philadelphia, 1876-1926 (Philadelphia: University of Pennsylvania Press, 2003); Katherine Grier, Culture and Comfort: Parlor Making and Middle-Class Identity, 1850-1930 (Washington, DC: Smithsonian Institution Press, 1997); Richard Bushman, The Refinement of America: Persons, Houses, Cities (New York: Vintage Books, 1993); Paul Boyer, Urban Masses and Moral Order in America, 1820-1920 (Cambridge: Harvard University Press, 1978).

${ }^{6}$ For early-nineteenth-century suburbanization, see Ronald Karr, "Suburban Land Development in Antebellum Boston," Journal of Urban History 41, no. 5 (2015): 862-880; Hayden, Building Suburbia, 21-44; Henry Binford, The First Suburbs: Residential Communities on Boston's Periphery, 1815-1860 (University of Chicago Press, 1985). ${ }^{7}$ Apart from introducing an emphasis on power relations and the social fault lines of race, gender, and class in the development of American suburbs, the "new suburban history" has also pointed out the middle-class bias in early scholarly work on suburbanization (see, for instance, Fishman and Jackson cited in footnote 3 above). The American suburban landscape, rather, was always diverse. See Wei Li, Ethnoburb: The New Ethnic Community in America (Honolulu: University of Hawaii Press, 2012); Andrew Wiese, Places of Their Own: African American Suburbanization in the Twentieth Century (University of Chicago Press, 2005); Robert Lewis, ed., Manufacturing Suburbs: Building Work and Home on the Metropolitan Fringe (Philadelphia: Temple University Press, 2004); Becky Nicolaides, My Blue Heaven: Life and Politics in the Working-Class Suburbs of Los Angeles, 1920-1965 (University of Chicago Press, 2002); Richard Walker and Robert Lewis, "Beyond the crabgrass frontier: industry and the spread of North American cities, 1850-1950," Journal of Historical Geography 27, no. 1 (2001): 3-19.
} 
Across the country, suburbanization increased through the first decades of the twentieth century, facilitated by improved transportation infrastructure. Bridges and tunnels supplanted ferry crossings, express trains compressed commuting times while extending the reach of suburbia, and automobile ownership increased from about 458,500 automobiles in 1910 to 23.2 million by $1930 .^{8}$ European immigrants moved to suburbs for service work or employment on nearby farms, and, when a million African Americans moved out of Southern states during the Great Migration, at least one in six Black migrants resettled in the suburbs. ${ }^{9}$ Although rates of suburban expansion plateaued during the 1930s, following World War II, a rebounding national economy, demand for new housing, the federal government's intervention in the housing market, and, by the 1950s, expansive federal funding of an interstate highway system spurred an unprecedented wave of suburbanization. ${ }^{10}$

In New Jersey, the social and economic forces fostering suburban desires in nineteenthcentury New York City and Philadelphia extended out into the state's northeastern and southwestern counties. Since the Colonial era, New Jersey's location between these two major cities positioned the state as a transportation corridor. ${ }^{11}$ By the 1850 s, the routes over which people, agricultural products, manufactured goods, and other commodities traveled between New York and Philadelphia facilitated these cities' residential expansion into their Garden State hinterlands. With land at a premium in Manhattan and limited water sources for industrial power,

\footnotetext{
${ }^{8}$ Teaford, 17.

${ }^{9}$ For Black suburbanization and the Great Migration, see Andrew Wiese, "The Other Suburbanites: African American Suburbanization in the North before 1950," The Journal of American History 85, no. 4 (1999): 1495-1524.

${ }^{10}$ For work emphasizing the unprecedented postwar expansion of suburbanization in the United States, see James Jacobs, Detached America: Building Houses in Postwar Suburbia (Charlottesville: University of Virginia Press, 2015); Bernadette Hanlon, John Short, and Thomas Vicino, Cities and Suburbs (New York: Routledge, 2010); Robert Beauregard, When America Became Suburban (Minneapolis: University of Minnesota Press, 2006); Hayden, 128154; Rosalyn Baxandall, Elizabeth Ewen, and Linda Gordon, Picture Windows: How the Suburbs Happened (New York: Basic Books, 2000); Gwendolyn Wright, Building the Dream (New York: Pantheon Books, 1981).

${ }^{11}$ Charles Stansfield, Jr., A Geography of New Jersey: The City in the Garden (New Brunswick: Rutgers University Press, 1998), 1-2.
} 
manufacturers tied to the New York City market sought factory locations between western Connecticut and northern New Jersey. By the late 1860s, New York's industrial market extended to Newark, Hoboken, and other industrial cities in North Jersey. ${ }^{12}$ With early picturesque enclaves such as Llewellyn Park paving the way, land companies turned swaths of Bergen, Essex, Passaic, and Union Counties into suburban communities for middle-class residents who commuted to work in New York City. ${ }^{13}$ By the middle of the twentieth century, the expansion of North Jersey cities, suburbs, and highway systems created a nearly unbroken metropolitan complex between New York City and New Jersey’s mountainous northwestern counties.

In South Jersey, suburbanization progressed at a different pace and in a different spatial register. A long history of Quaker business and family ties and shared natural resource dependency created a common cultural and economic sphere between Philadelphia and South Jersey. ${ }^{14}$ Ferries had connected the city with New Jersey riverfront communities since the late seventeenth century. ${ }^{15}$ The market for goods from Philadelphia stretched down the Delaware estuary. In return, the city received flows of products from South Jersey, including produce, fish, livestock, and oysters, as well as lumber and fuelwood from the Pine Barrens. In the 1770s, when Jacob Cooper subdivided his family's farm and advertised building lots, he established Camden as Philadelphia’s

\footnotetext{
12 Ann Marie Cammarota, Pavements in the Garden: The Suburbanization of Southern New Jersey, Adjacent to the City of Philadelphia, 1769 to the Present (Madison: Fairleigh Dickinson University Press, 2001), 85; Edwin Burrows and Mike Wallace, Gotham: A History of New York City to 1898 (New York: Oxford University Press, 1999), 659662.

${ }^{13}$ See Thomas Rudel, Karen O’Neill, Paul Gottlieb, Melanie McDermott, and Colleen Hatfield, "From Middle to Upper Class Sprawl? Land Use Controls and Changing Patterns of Real Estate Development in Northern New Jersey," Annals of the Association of American Geographers 101, no. 3 (2011): 609-624; Richard Wilson, "Idealism and the Origin of the First American Suburb: Llewellyn Park, New Jersey," American Art Journal 11, no. 4 (1979); 79-90.

14 Allison Hayes-Conroy, South Jersey Under the Stars: Essays on Culture, Agriculture, and Place (Madison: Fairleigh Dickinson University Press, 2005); Cammarota, 12.

${ }^{15}$ John Black, Excursion on the Delaware: A History of Steamboats and Their Men in the Delaware Valley, ed. Ruthe Baker (Woodbury: Gloucester County Historical Society, 1993); Charles Boyer, "Early Transportation Across the Delaware. A paper read at the Annual Meeting of the Gloucester County Historical Society, January 8, 1924.” Unpublished manuscript. Gloucester County Historical Society, Woodbury, NJ.
} 
first residential suburb in New Jersey. ${ }^{16}$ By 1850 , Camden was more Philadelphia's neighboring city than a suburb, with 9,479 residents, a growing industrial base, and the terminus of the Camden \& Amboy Railroad linking, via ferry, Philadelphia with New York City. As Camden became a manufacturing and transportation hub, the rural Camden County communities of Collingswood, Haddon Heights, Haddonfield, and Merchantville became attractive suburban communities for Camden's middle class. ${ }^{17}$

Away from the Delaware River, however, overland travel remained difficult through the 1860s. Although in 1830 the New Jersey legislature granted the Camden \& Amboy Railroad a charter to control canal and rail lines between New York and Philadelphia, no similar transportation ventures were granted charters in South Jersey until the 1850 s. ${ }^{18}$ In 1853 , the legislature granted a charter for the West Jersey Railroad. Over the next ten years, the West Jersey and its subsidiaries opened a line from Camden to Woodbury, south to Glassboro, Millville, and, by 1863 , to Cape Island (later Cape May City). ${ }^{19}$ In 1854 , a second railroad company, the Camden \& Atlantic Railroad, completed a line from Camden to the new coastal resort of Atlantic City. ${ }^{20}$ Through the 1890s, additional lines linked Camden with communities in Cumberland and Salem Counties, and shore communities in Atlantic and Cape May Counties. The completion of these rail lines spurred speculative plans for new towns, agricultural settlements, and immigrant communities throughout South Jersey. ${ }^{21}$ The rising value of land along the lines also accentuated

${ }^{16}$ Cammarota, 12-13, 85-88; Jeffery Dorwart, Camden County New Jersey: The Making of a Metropolitan Community, 1626-2000 (New Brunswick: Rutgers University Press, 2001).

${ }^{17}$ Dorwart, 161.

${ }^{18}$ Lorett Treese, Railroads of New Jersey: Fragments of the Past in the Garden State Landscape (Mechanicsburg: Stackpole Books, 2006).

${ }^{19}$ Treese, 191-93; Jeffery Dorwart, Cape May County, New Jersey: The Making of an American Resort Community (New Brunswick: Rutgers University Press, 1992), 93-99, 110-111.

${ }^{20}$ Martin Paulsson, The Social Anxieties of Progressive Reform: Atlantic City, 1854-1920 (New York University Press, 1994), 14-56.

${ }^{21}$ See Elizabeth Marsh, Mark Demitroff, and Paul Schopp, "The Southern Pine Barrens: An Ethnic Archipelago," SoJourn: A Journal Devoted to the History, Culture, and Geography of South Jersey 3, no. 2 (Winter 2018/2019): 7- 
the potential of established communities in Camden and Gloucester Counties as exurbs offering country living to residents of Camden and Philadelphia. ${ }^{22}$ Following the Civil War, amid a resurgence of predominantly Methodist revivalism, rail lines also offered convenient locations for camp meeting revivals.

\section{Pitman Grove}

Camp meeting revivalism is a religious phenomenon with roots in the early-nineteenthcentury revivals of the Second Great Awakening. ${ }^{23}$ By the 1810 s, camp meetings became Methodism's grand outdoor theaters, drawing thousands of Methodists, potential converts, and curious observers for a week to ten days of preaching, prayer, fellowship, and ecstatic displays of religious conversion. Camp meeting revivals helped drive denominational growth such that by the 1840s, the Methodist Episcopal Church was the largest Protestant denomination in the United States. However, the denomination's growing ranks of urban middle-class members and seminarytrained clergy consigned camp meeting revivalism to the denomination's rural past.

By the 1860s, Methodists returned to the practice of camp meeting revivalism. Their new camp meeting grounds combined nostalgia for traditional Methodist practice with new middleclass desires for country living. Many postwar camp meetings developed into religious resort communities offering a moral alternative to secular resorts. ${ }^{24}$ Methodists were prolific in founding

\footnotetext{
25; Samuel Avery-Quinn, “'The Greatest Agricultural Colony on Earth': Landscape and Community Development of the Estelle Colony, Atlantic County, New Jersey, 1895-1910," Pennsylvania History: A Journal of Mid-Atlantic Studies 85, no. 4 (2018): 488-529.

${ }^{22}$ Exurbs are suburbs that are not spatially contiguous with a city and are surrounded by rural countryside — see Arthur Nelson, "Characterizing exurbia," Journal of Planning Literature 6, no. 4 (1992): 350-368.

${ }^{23}$ See Russell Richey, Methodism in the American Forest (New York: Oxford University Press, 2015); Kenneth O. Brown, Holy Ground: A Study of the American Camp Meeting (New York: Garland, 1992); Charles Johnson, The Frontier Camp Meeting: Religion's Harvest Time (Dallas: Southern Methodist University Press, 1955).

${ }^{24}$ Roger Robins, "Vernacular American Landscapes: Methodists, Camp Meetings, and Social Respectability," Religion and American Culture: A Journal of Interpretation 4, no. 2 (1994): 165-191; Randall Balmer, "From Frontier Phenomenon to Victorian Institution: The Methodist Camp Meeting in Ocean Grove, New Jersey," Methodist History 25, no. 3 (1987): 194-200; Charles Parker, "The Camp Meeting on the Frontier and the Methodist Religious Resort in the East—Before 1900," Methodist History 18, no. 3 (April 1980): 179-192.
} 
over 150 camp meeting towns by 1890 . In New Jersey, Methodists strung postwar camp meeting grounds along rail lines from New York City and Philadelphia and along the Jersey Shore. Each summer, inland Methodist towns from Mount Tabor south to Malaga swelled with hundreds of residents and thousands of visitors. Along the coast, camp meeting resorts at Atlantic Highlands, Ocean City, and Ocean Grove drew tens of thousands of summer visitors and mirrored the rapid growth of secular shore resorts. ${ }^{25}$

In 1866, South Jersey Methodists celebrated the centennial of American Methodism by holding a camp meeting near Barnsboro in Gloucester County, 15 miles south of Camden, on the West Jersey Railroad line. ${ }^{26}$ They christened the woodland site, leased from local farmer J. T. Turner, the "Centennial Camp Meeting." For the next three years, the meeting drew large crowds each summer. ${ }^{27}$ Although convenient to Philadelphia by rail, the forest canopy was not dense, the soil was dusty, and water was scarce. At the close of the 1869 revival, Rev. William Perry of Bridgeton held a meeting to purchase "grounds on which to locate permanently this meeting, convenient to the City of Philadelphia and at some point south of Camden."28

In 1871, Perry's group bought 60 acres one mile south of Turner's woods. ${ }^{29}$ They named the site Pitman Grove, in honor of Rev. Charles Pitman (d. 1854), a popular revivalist. With a

\footnotetext{
${ }^{25}$ Samuel Avery-Quinn, Cities of Zion: The Holiness Movement and Methodist Camp Meeting Towns in America (Lanham: Lexington Books, 2019); Troy Messenger, Holy Leisure: Recreation and Religion in God's Square Mile (Philadelphia: Temple University Press, 2000).

${ }^{26}$ Dolores Allen, "Barnsboro United Methodist Church," The Historical Trail-Yearbook of Conference Historical Society and Commission on Archives and History, Southern New Jersey Conference, The United Methodist Church 32 (1995):105-114; Robert Steelman, What God Has Wrought: A History of the Southern New Jersey Conference of the Methodist Church (Pennington: United Methodist Church, Southern New Jersey Annual Conference, Commission on Archives and History, 1986), 82-88; John Cawman Eastlack, Gloucester County in the Eighteen-Fifties: Being the Diary of John Cawman Eastlack (Woodbury, NJ: Gloucester County Historical Society, 1982), 46-52.

${ }^{27}$ In August 1869, a reporter observed that attendance had swelled "to about ten thousand. As the preaching is in progress about every seat, even upon the outer limits of the circle is occupied." See "The Barnsboro Camp Meeting," The Philadelphia Inquirer, August 17, 1869, 3.

${ }^{28}$ Minutes of the New Jersey Conference Camp Meeting Association (NJCCMA), August 17, 1869. Pitman Grove Collection, Pitman Historical Museum, Pitman, New Jersey.

${ }^{29}$ NJCCMA Minutes, April 28, 1871.
} 
charter from the state legislature, Perry's group became the New Jersey Conference Camp Meeting Association. Perry arranged for Philadelphia architect Samuel Sloan to design their "proper, convenient, desirable and permanent camp meeting grounds." 30 In May, Perry showcased the plan for a central worship area with 12 narrow avenues radiating out to a surrounding belt road with 20-by-30-foot lots for tents and other structures between the avenues. The Association's decision to hold their first ten-day revival starting on July 25 left little time to implement Sloan's plan beyond the wagon wheel-shaped area. ${ }^{31}$ The Association later hired surveyors to divide areas beyond the core into 30-by-40-foot lots. As new purchases expanded the grounds to 230 acres, the Association divided outlying land into larger, half-acre lots.

In time for their inaugural revival, the Association cleared a central worship area and erected a rectangular preaching pavilion fronted by plank benches. While attendees bid on tenting lots, the Association built a boardinghouse and restaurant, dug privies and water pumps, and worked with the West Jersey Railroad to build a passenger platform. ${ }^{32}$ Camp meetings at Pitman Grove soon drew hundreds of attendees from South Jersey and even larger numbers by train from Camden and Philadelphia. Stepping off a train, visitors found traditional worship services, fiery sermons, prayer meetings, and fellowship that many may have remembered from their childhood. ${ }^{33}$

\footnotetext{
${ }^{30}$ NJCCMA Minutes, April 28, 1871; Minutes, May 15, 1871.

${ }^{31}$ Charles Stansfield suggests the Association's implementation of the plan was a haphazard affair, leaving uneven spacing between avenues and irregular lot sizes in the wagon wheel area. See Charles Stansfield, "Pitman Grove: A Camp Meeting as Urban Nucleus," Pioneer America 7, no. 1 (1975): 36-44.

${ }^{32}$ By 1873, the grounds included a preaching pavilion, boardinghouse, restaurant, an office building, a cottage, a stable, a butcher's shop, 20 water pumps, and 13 privies. See Annual Report of the President of the New Jersey Conference Camp Meeting, August 1873. Pitman Grove Collection, Pitman Historical Museum, Pitman, New Jersey.

${ }^{33}$ For a description of common rhythms of Methodist camp meeting revivals by the 1830 s, see Nathan Bangs, $A$ History of the Methodist Episcopal Church, vol. 2 (New York: Mason and Lane, 1838), 266-267. For a description of worship services at Pitman Grove in the late 1880s, see Dougan Clark and Joseph Smith, David B. Updegraff and His Work (Cincinnati: M. W. Knapp, 1895), 169-171.
} 


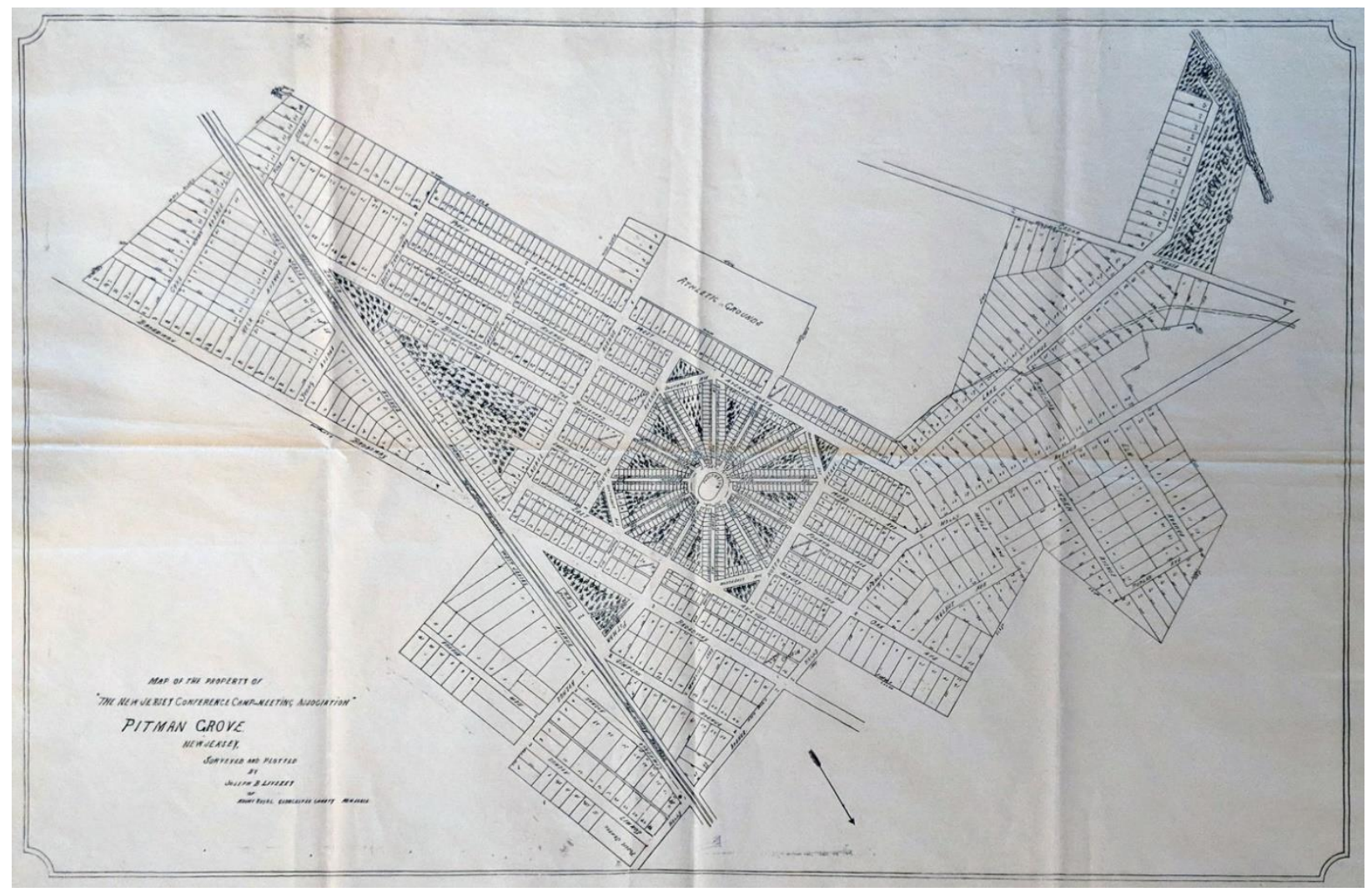

Map of the Grounds of the New Jersey Conference Camp Meeting Association, circa 1905. ${ }^{34}$

However, Pitman Grove's resemblance to an old-fashioned camp meeting did not last long. The directors soon allowed attendees to build small cottages for an annual lease, later changed to a single payment for a 99 -year lease like those at other camp meeting towns. ${ }^{35}$ Not only would cottages allow attendees to extend their stays on the grounds, the cottages also offered an opportunity to enjoy country residence in a community that claimed to be free from the ills and vices of the industrial city and fashionable watering places. The revenue from leasing cottage lots

\footnotetext{
${ }^{34}$ Joseph Liveley, "Map of the Property of the New Jersey Conference Camp Meeting Association, Pitman Grove, New Jersey." Undated map, uncertain scale. Courtesy Pitman Historical Museum, Pitman, NJ.

${ }^{35}$ Leasing, rather than selling lots allowed camp meeting associations to maintain legal ownership and control of their grounds. Leasing plans were common among camp meetings in New Jersey, although some Methodist ventures, such as Ocean City, in Cape May County, sold, rather than leased, lots. At Pitman Grove, the association's lot-leasing program continued through the 1960s.
} 
sustained Pitman Grove's revivals, and the growing number of cottages would transform the grounds into a summer community mostly for middle-class white Methodists from Camden and Philadelphia.

\section{Suburbanization}

By 1873, local builders erected 43 cottages at Pitman Grove. Methodists first erected cottages in the early 1860s at the Wesleyan Grove Camp Meeting on Martha's Vineyard, Massachusetts. ${ }^{36}$ Wesleyan Grove cottages displayed Carpenter or Rural Gothic styles with elaborate front façades, double doors, narrow windows topped by scrollwork finishes, and ornate trim under balconies and eaves. Early Pitman Grove cottages were rough approximations of the Massachusetts models: plain vernacular structures with board-and-batten exteriors wrapped like a thin skin around their wood frames. Pitman Grove cottage interiors emphasized a front parlor with sleeping quarters in the rear of one-story cottages, or upstairs in larger cottages. As the number of cottages swelled to over 600 by 1895, cottagers rebuilt or replaced many older cottages with larger, two-story structures with Rural Gothic exteriors and well-furnished interiors. ${ }^{37}$

The 1880s and 1890s were boom years for Pitman Grove. Builders erected dozens of new cottages each year and built more substantial houses on multiple adjoining lots outside the wagon wheel core. By the early 1880s, hundreds of Methodist families made Pitman Grove their summer home. ${ }^{38}$ In the 1890 s, as revivals drew tens of thousands of visitors in addition to residents,

\footnotetext{
${ }^{36}$ Ellen Weiss, City in the Woods: the life and design of an American camp meeting on Martha's Vineyard (New York: Oxford University Press, 1987).

37 "Special Telegram to the Times," The Times (Philadelphia, PA), August 1, 1895, 3.

${ }^{38}$ In 1885, 35 families made Pitman Grove their year-round home-a number that would continue to increase in subsequent years. Harold F. Wilson, Cottagers and Commuters: A History of Pitman, New Jersey (Pitman, NJ: Borough of Pitman, 1955), 23.
} 
Camden and Philadelphia newspapers declared Pitman Grove to be South Jersey's "Methodist Mecca." 39

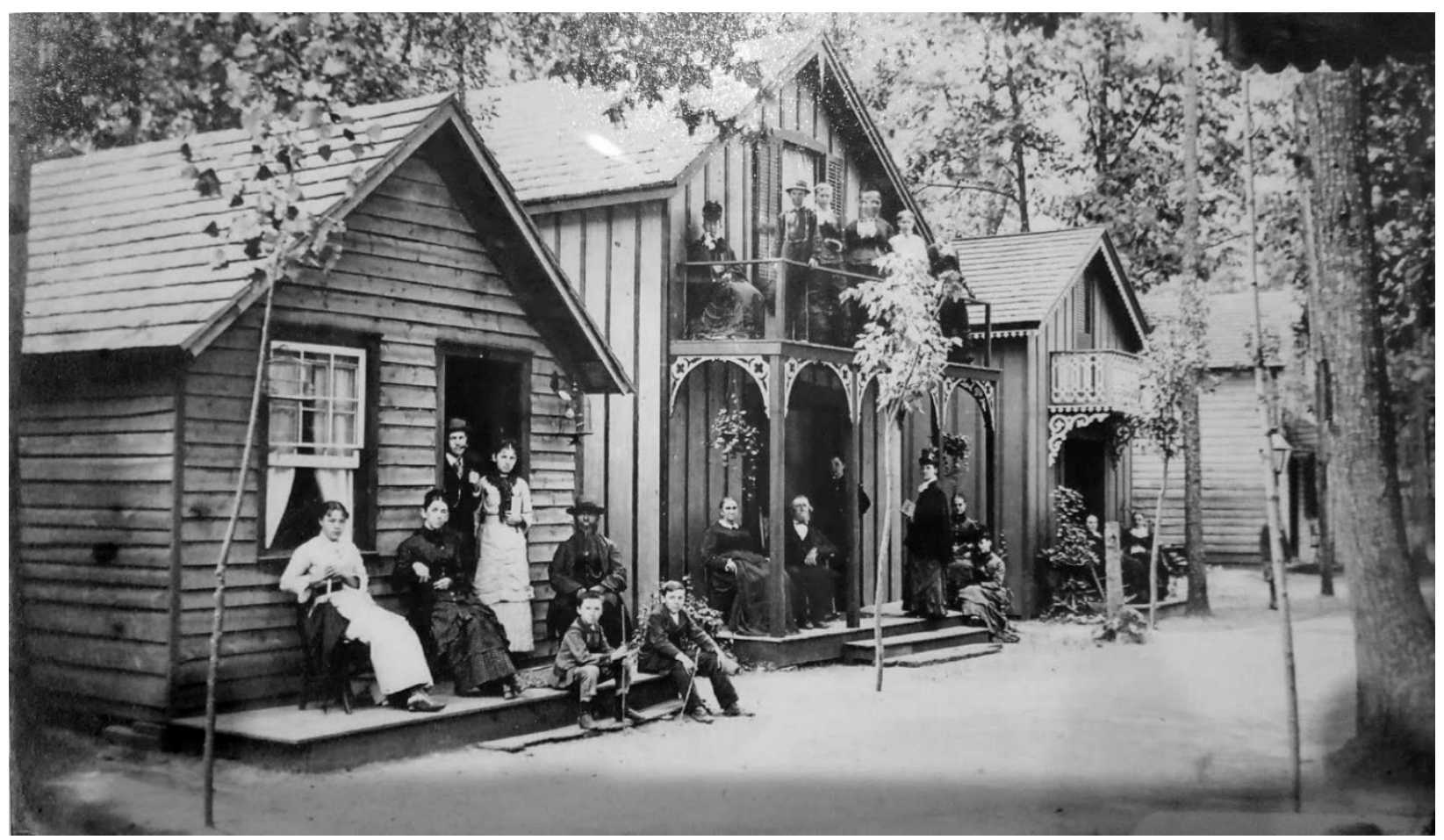

Cottages in Pitman Grove, circa 1880. ${ }^{40}$

Like other Methodist camp meetings, Pitman Grove's popularity rested with a predominantly white cross section of middle-class urban Methodists. The cost of cottage ownership, extended stays, and segregated hotels and amenities limited African American vacationing opportunities. ${ }^{41}$ Further, Pitman Grove, unlike Methodist resorts at Ocean City and Ocean Grove, did not have a comparable number of hotels and other businesses to employ African American workers - although wealthier families likely relied on the services of Black domestic

\footnotetext{
${ }^{39}$ See, for instance, "Political Talk at Pitman Grove," The Philadelphia Inquirer, August 4, 1893, 5.

${ }^{40}$ Pitman Grove Collection. Courtesy Pitman Historical Museum, Pitman, NJ.

${ }^{41}$ For the historical experience of African Americans at predominantly white resorts, see Myra Armstead, Lord, Please Don't Take Me in August: African Americans in Newport and Saratoga Springs, 1870-1930 (Urbana: University of Illinois Press, 1999). In her autobiography, holiness advocate Amanda Berry Smith describes how her visits to Ocean Grove began with her work as a domestic servant. See Amanda Berry Smith, The Story of the Lord's Dealings with Mrs. Amanda Smith (Chicago: Meyer and Brother, 1893), 218.
} 
servants. $^{42}$ Despite the economic limits and social restrictions on Black participation, the Association, at first, regularly extended invitations to prominent preachers from the African Methodist Episcopal Church. Through the 1880s, AME Bishop Jabez Pitt Campbell included Pitman Grove in his summer preaching, followed, in the 1890s, by Bishop Abram Grant. ${ }^{43}$

While the Association boasted of the spirit of ecumenicism that brought AME bishops and representatives of other denominations to their grounds, the traditional revival character of Pitman Grove was changing. While pleased with their community's growth, the Association was wary of growing demands for leisure and recreation. Their reluctance stemmed from a commitment to fostering a moral community centered around worship. ${ }^{44}$ Promoting such a community, the Association imposed strict rules for public etiquette, temperance, and the sanctity of the Sabbath. The Association prohibited loud talking and promenading near the central worship area. No attendee could have alcohol on the grounds, and every camp meeting began with a temperance

\footnotetext{
${ }^{42}$ In 1860, the free Black population of South Jersey was at least 9,853. Among South Jersey towns, Camden had a sizeable Black population, and, near Pitman, Woodbury had a growing Black neighborhood. Several free Black communities, such as Free Town (later Lawnside), Guineatown, and Saddlertown were also a relatively short commute away from Pitman. Through the early twentieth century, seasonal employment shifted the Black landscape of South Jersey from railroad work to glass factories, farms, and work in the oyster industry on the Delaware Bay. Domestic work and labor at camp meetings such as Pitman Grove would have been opportunities for employment during midsummer lulls in agricultural employment. For histories of African American communities in South Jersey, see Michael Chiarappa, "Working the Delaware Estuary: African American Cultural Landscapes and the Contours of Environmental Experience," Buildings \& Landscapes: Journal of the Vernacular Architecture Forum 25, no. 1 (2018): 64-91; Wendel White, Deborah Willis, Stedman Graham, and Clement Alexander Price, Small Towns, Black Lives: African American Communities in Southern New Jersey (Oceanville: Noyes Museum of Art, 2003); Giles Wright, Afro-Americans in New Jersey: A Short History (Trenton: New Jersey Historical Commission, 1988). See also Water Greason, Suburban Erasure: How the Suburbs Ended the Civil Rights Movement in New Jersey (Madison: Fairleigh Dickinson University Press, 2013).

${ }^{43}$ See "Worship in the Woodlands," The Times, August 14, 1899, 11; "Pitman Grove," The Philadelphia Inquirer, August 9, 1882, 3; "Pitman Grove Camp Meeting," The Daily News (Lebanon, PA), August 17, 1874, 1.

${ }^{44}$ The Association's wariness also stemmed from their relationship with the camp meeting resort of Ocean Grove. Rev. Elwood H. Stokes, the first president of the popular Jersey Shore resort, was a founder of Pitman Grove, and Rev. Aaron Ballard, Pitman's third president, was the vice president of Ocean Grove - in the 1910s, Ballard served as president of both camp meetings. As Ballard described the relationship, "the encampments were so arranged as to not conflict in dates and ... many of the attendants upon the one were attendants upon the other." A competing Methodist resort a short train ride from Philadelphia would have been problematic for Ocean Grove. See Aaron Ballard, "A Letter from Dr. Ballard," Pitman Grove Review, April 2, 1913, 2; For Ballard's work at Ocean Grove, see Morris Daniels, The Story of Ocean Grove Related In the Year of its Golden Jubilee (New York: Methodist Book Concern, 1919).
} 
celebration. Sabbatarian measures included closing gates on Sundays, shuttering businesses, and preventing trains from stopping at the grounds during the Sabbath. The directors also banned vendors of such novelty treats as boiled peanuts, candy, ice cream, and lemonade. However, by the mid-1880s, they relented and allowed a merchant to run an ice cream saloon and confectionery. $^{45}$

By the mid-1890s, the Association also began to compromise their stance against leisure and recreation. In 1894, a group of cottagers organized the Pitman Grove Cottagers Association. ${ }^{46}$ For the next 62 years, their organization would provide entertainment, act as a village improvement society, and introduce leisure and recreation to the grounds. The Cottagers Association organized concerts, hymn sings, children's pageants, Fourth of July fireworks, and parades. By 1907, the Cottagers Association members, 200 of whom were women, worked to beautify the grounds with flower beds, benches, and gravel paths. ${ }^{47}$ They maintained Sunrise and Sunset Parks, built an amphitheater, and opened an athletics field. By 1890, the field featured tennis courts, space for quoits, and a baseball diamond. In 1895, cottagers formed a baseball club and soon had a new baseball park and pavilion. ${ }^{48}$

However, the Cottagers Association's offerings were not the only leisure opportunities available to Pitman Grove's Methodists. Nearby, sawmill owner Charles Wynne owned 190 acres of land surrounding a three-quarters-of-a-mile-long millpond. ${ }^{49}$ Catering to his Methodist

\footnotetext{
${ }^{45}$ While the directors of Methodist camp meeting associations often viewed the use of tobacco as, at best, unseemly, and, at worst, morally questionable, at Pitman Grove, the association only prohibited the sale of tobacco and banned smoking in the central worship area. As multiple attendees reported, however, tobacco was commonly used and surreptitiously for sale on the grounds. See "Pitman Grove," The Philadelphia Inquirer, July 13, 1886, 3.

46 "A Short History of the Summer Cottagers' Association of Pitman Grove, N.J.," Pitman Grove Review (Pitman, NJ), December 8, 1904, 4; Annual Reports of the Pitman Grove Cottagers' Association, Pitman Grove Collection, Pitman Historical Museum, Pitman, New Jersey; see also Wilson, 82-85.

47 "Features Which Help to Make it Popular," Courier-Post (Camden, NJ), September 18, 1907, 10.

${ }^{48}$ For the team's 1903 schedule, see "Pitman Baseball Team," Pitman Grove Review, July 16, 1903, 3; see also Wilson, 85.

49 “Pitman Yesterday," The Morning Post, (Camden, NJ), August 9, 1887, 1.
} 
neighbors, Wynne cleared land for a picnic ground and built a dock from which he rented boats. In 1888 , Wynne's health, like the finances of his mill, was in decline. ${ }^{50} \mathrm{He}$ sold the property to George Washington Carr, a Methodist carpenter from Richwood. ${ }^{51}$ In 1892, Carr and his brother Henry renamed the millpond as Alcyon Lake and transformed much of the mill property into an amusement resort, Alcyon Park. For Pitman Grove's Methodists, Alcyon Park was both a threat and an opportunity. For some, the amusement park intruded on the seclusion of the camp meeting. ${ }^{52}$ However, Carr's Methodist values and temperance stand fostered a symbiotic relationship. By 1910, the Carr brothers boasted "a bicycle track, baseball ground, casino seating 1,000 persons where Vaudeville and comedy performances take place, eight bowling alleys, merry-go-round, roller skating rink and a figure-eight toboggan slide [and] two large restaurants. ${ }^{, 53}$ Pitman Grove Methodists were among their most loyal patrons.

While tensions between Alcyon Park and Pitman Grove were few, other challenges emerged - challenges to which the Association had, in part, contributed. Although the directors leased lots so that the Association retained ownership of the land under the cottages, such was not always the case. Following the Panic of 1873, the Association sold 75 lots outside the wagon wheel. ${ }^{54}$ In October 1882, stockholders, complaining they had received only paltry dividends, forced the Association to sell dozens of outlying lots. ${ }^{55}$ Visiting in 1887 , a reporter noted that

50 "Down in the Grove," The Morning Post, August 7, 1888, 1.

51 Warren Carr, grandnephew of George W. Carr, in discussion with the author, March 2019; see also "George Washington Carr," Biographical, Genealogical, and Descriptive History of the First Congressional District of New Jersey, Vol. 2 (New York: Lewis Publishing Company, 1911), 94.

52 “At Powerful Pitman," The Morning Post, August 7, 1895, 1. For an extended discussion of tensions over leisure that summer, see Charles Parker, Pitman Grove, New Jersey: Through a Tiffany Window (Woodbury: Gloucester County Historical Society, 1984), 105-107.

53 “Alcyon Park: Pleasure Resort at Pitman, New Jersey," Brochure, circa 1910, Alcyon Park Collection, Pitman Historical Museum, Pitman, New Jersey.

54 Directors' Report of Assets and Liabilities to the Stockholders of the New Jersey Conference Camp Meeting Association, October 1, 1889. Pitman Grove Collection, Pitman Historical Museum, Pitman, NJ.

55 NJCCMA Minutes, October 3, 1882. 
northeast of the grounds, "there's a great demand for dwelling houses on Arbutus Hill." "56 The following year, the Arbutus Hill neighborhood seemed "quite a village of itself. It has a store, beef market, dining rooms, ice cream saloon, barber shop, and a new Methodist Protestant Church. On the east they have a lumber, wood and coal yard, livery stable, real estate office and a public schoolhouse." $" 57$

Arbutus Hill businessmen squabbled with the Association through the 1890s. Fights erupted over Mantua Township tax rates, keeping businesses open on Sundays, relocating a post office from the Grove to Arbutus Hill, and a failed petition for the West Jersey Railroad to open a passenger platform at Arbutus Hill and thereby skirt the Association's ban on Sunday train service. ${ }^{58}$ Their efforts intensified with the organization of a newspaper, a building and loan association, and a board of trade. In 1903, William "W. L." Peterson launched the Pitman Grove Review. Peterson's editorials praised "Greater Pitman" as the most "desirable location along the line of the railroad ... for convenience, and pure air and water and health."59 Among the paper's first advertisers were real estate listings by D. S. Pancoast, Charles Justice, W. Stewart Dilkes, and grocer turned real estate agent Joseph “J. M.” McCowan. Interspersed among the real estate listings were advertisements for low-cost mortgages offered by the Pitman Building and Loan Association, as well as ads for lumber from George Carr's mill. Tying these business ventures together was a Board of Trade led by Charles Justice.

In 1904, the Board of Trade was instrumental in establishing "Greater Pitman" as a secular borough. Complaints about poor roads, taxes, and a lack of funds for the community's school

\footnotetext{
56 "Pitman Grove," The Morning Post, April 5, 1887, 1.

57 "Down in the Grove," The Morning Post, August 7, 1888, 1.

${ }^{58}$ Parker, Pitman Grove, 94-107; "Pitman Grove Camp," Courier-Post, August 2, 1893, 1; "Pitman Yesterday," The Morning Post, August 9, 1887, 1.

${ }^{59}$ See, for instance, W. L. Peterson, "Editorial," Pitman Grove Review, July 30, 1903, 2.
} 
became a rallying cry for incorporation. ${ }^{60}$ In October 1904, during the camp meeting's off-season, the board held a community meeting at which attendees voted for incorporation. ${ }^{61}$ In March 1905, when board delegates visited Trenton, they encountered an irate Aaron Ballard, who claimed that the measure would strip the Association's long-held municipal authority and would only be a boon for real estate speculators. ${ }^{62}$ He urged the legislature to reject the measure or, at the very least, exclude Pitman Grove from the new borough. Despite Ballard's opposition, the borough bill passed, and on May 24, 1905, Governor Edward C. Stokes signed the bill establishing the Borough of Pitman. One month later, members of the Board of Trade swept the borough's first election, seating J. M. McCowan as Mayor and creating a political machine that would govern Pitman for decades. $^{63}$

Over the next five years, Pitman's population nearly doubled to 1,950 residents, many of whom moved to the borough under the sway of advertisements from land companies. ${ }^{64}$ The four largest ventures were D. S. Pancoast's Pitman Highlands; Charles Justice's Glen Lake; Pitman Grove Terrace, developed by the Philadelphia Suburban Company (a local venture managed by W. Stewart Dilkes); and Pitman Heights, sold by William T. B. Roberts, a developer of housing

\footnotetext{
${ }^{60}$ A desire for municipal services was a common reason for the incorporation of suburban communities. As John Teaford notes, suburban advocates of incorporation framed such a move as upholding the shared values of a community. For late-nineteenth-century, predominantly white suburban communities, often this meant enshrining Protestant preferences for temperance and bans on saloons into municipal code. However, such "home rule" municipalities, seeking to preserve the physical and social character of their community, enacted restrictions on land use and permissible building construction that created barriers for low-income and minority families. See Teaford, 13-14; for the discriminatory dimensions of "home rule," see Becky Nicolaides and Andrew Weise, "Suburbanization in the United States after 1945," in Oxford Research Encyclopedia of American History. Accessed July 28, 2020, https://doi.org/10.1093/acrefore/9780199329175.013.64, and David Freund, Colored Property: State Policy and White Racial Politics in Suburban America (University of Chicago Press, 2007).

61 "Town Meeting," Pitman Grove Review, September 17, 1903, 1.

62 "Ballard Opposes Bill," Asbury Park Press (Asbury Park, NJ), March 2, 1905, 1.

63 “Former Camden Man Named for Mayor," Courier-Post, June 15, 1905, 3. Although the borough's mayors were nominally independent of political party affiliations through the 1910s, each had close ties to the Board of Trade. By the 1930s, however, Pitman's Council and mayor's office, like most public offices in South Jersey, were safe seats for Republicans.

${ }^{64}$ For an extended discussion of Pitman land companies, see Wilson, 102-114.
} 
tracts in the Philadelphia suburbs. ${ }^{65}$ The companies surveyed and cleared tracts, laid out curbed streets with sidewalks, and installed water and gas lines and electric lights. They also launched advertising campaigns in Camden and Philadelphia and held free picnics at Alcyon Park for prospective buyers. "Its perfect natural drainage, pure water, a beautiful lake of clear spring water, convenient train service, extra-large lots, broad avenues with wide sidewalks make it the most attractive place for a home in south Jersey," Charles Justice claimed of Glen Lake. ${ }^{66}$ Such appeals

\section{Why Is Pitman Grove Terrace}

\section{So Popular?}

Why Is It Building up So Rapidly? BECAUSE OF ITS MANY ADVANTAGES

Here are some of them: location, right at Pitman Station, High-speedElectric Trains, over 70 a day, low fare. High elevation, insuring excellent drainage, cool breezes and no mosquitoes; elegant shade; broal, well-graded avenues, and wide cement sidewalks. City conveniences, including water, gas and electricity. Protective restrictimns, insuring good neighbors and pretty homes. 24 diwellings, costing when finished $\$ 80,000$, and as many more coniracted far, samz of which will cost nsanly $\$ 10,000$ sach, and a handsome steng church odifice under way, all since ths "Terrace" was apgnet ans yaar age. Over 300 satiafiad custamers. "This is the avidance of its fopularity."

Write for Booklet showing some of the pretty houses now built, and the "Good Things" we have for you this season. Our terms are easy,

Commuters down the lige, come to Pitman, where the carfare is low and attractions innumerabie :

Pitman Is the Most Popular Inland Resort Within Fifty Miles of Philadelphia

\section{Philadelphia Suburban Co.}

\section{PITMAN, N. J.}

OFFICES IN DILKS BUILDING BELL PHONE $67 \mathrm{~A}$ were frequent in the companies' advertising, framing the borough as an affordable, conveniently located, and healthy suburb.

Prices ranged from $\$ 50$ to $\$ 275$ for what were typically one-acre lots. Companies advertised payments as low as $\$ 5$ down and $\$ 5$ a month, discounts for lots paid in full, and no property taxes for two years. Despite their emphasis on affordability, companies were careful to position their properties as only suitable for middle-class buyers. As W. Stewart Dilkes described Pitman Terrace, "only persons of good moral character will be

Advertisement for Pitman Grove Terrace (1908).

\footnotetext{
${ }^{65}$ By the 1910s, area newspapers published more articles about and advertisements for these four land companies combined than the papers published articles covering the annual camp meeting. For examples see "Some Newsy Bits from Lively Resort," Courier-Post, September 23, 1913, 7; "Conditions Good in Jersey Mart," The Philadelphia Inquirer, May 22, 1910, 6; "Terrace Lots Going Fast," The Morning Post, July 23, 1907, 6; "Big Boom at Pitman Grove," Courier-Post, June 27, 1907, 9.

66 “The Glen Lake Tract," [advertisement] Camden Daily Courier (Camden, NJ), June 6, 1907, 10.
} 
allowed ownership. The ground is restricted as to the manufacture and sale of liquor. No residences can be built to cost less than $\$ 1,500 .{ }^{.67}$

Such suburban living was possible, the companies cajoled prospective middle-class buyers, because of "splendid train service, it being possible to reach the city [Philadelphia] in 27 minutes by boarding any one of the 80 trains that are operated each day." 68 In 1907 , when the West Jersey Railroad installed electrified tracks for express service between Camden and Atlantic City, Pitman advertisements boasted rising land values. ${ }^{69}$ While land companies emphasized affordability, healthy country living, and convenience, on occasion they spoke highly of how the camp meeting shaped the borough's moral environment.

Through incorporation and a building boom, camp meetings in the Grove continued much as they had in previous years. The program for 1905 announced a temperance day, celebrations of the women's foreign and home missionary societies, sermons by the Presiding Elders of the Camden and Bridgeton Districts, and a keynote sermon by Rev. W. D. Parr, Secretary of the Methodist Church Extension Society. ${ }^{70}$ In 1909, W. L. Peterson wrote of another "great camp meeting" with sermons preached before "fairly good congregations."71 Such praise would become less frequent through the 1910s.

After 1910, camp meetings at Pitman Grove were rare topics in the Camden and Philadelphia papers. The network of preachers headlining the annual revival shrunk to ministers from the New Jersey and Philadelphia annual conferences, with an occasional preacher arriving

\footnotetext{
67 "Pitman Makes Rapid Strides," [advertisement] The Morning Post, May 29, 1908, 4. As Cammarota notes in a review of early-twentieth-century deeds and housing contracts in Collingswood and Haddon Heights in neighboring Camden County, given typical annual earnings, deeds specifying between $\$ 1,500$ and $\$ 3,000$ for a minimum construction price meant that such houses were only affordable for white-collar workers. See Cammarota, 120.

68 "Conditions Good in Jersey Mart," The Philadelphia Inquirer, May 22 ,1910, 6.

69 "Big Boom at Pitman Grove," Courier-Post, June 27, 1907, 9.

${ }^{70}$ Pitman Grove Camp Meeting Program, 1905. Pitman Collection, Gloucester County Historical Society, Woodbury, NJ.

71 "Camp Flashes," Pitman Grove Review, August 2, 1909, 2.
} 
from elsewhere. As historian William Warren Sweet observed, by the early twentieth century, the emotional religion on which camp meeting revivalism had long depended was becoming less appealing for growing numbers of well-educated Methodists. ${ }^{72}$ Revivalism faced pushback even from conservative Protestants, who argued that personal evangelism rather than mass revivals could be a more effective means of winning souls. ${ }^{73}$

To the degree that a cultural shift in revivalism contributed to the shrinking crowds at Pitman Grove, so too did late-nineteenth-century schisms as growing numbers of holiness advocates established new denominations. ${ }^{74}$ Although advocates had been regular attendees at Pitman Grove's camp meetings, by the 1930s, they had several holiness camp meetings to choose from in South Jersey. In 1895, holiness advocates, including several founders of Ocean City, established the Delaware riverfront resort of National Park, 12 miles northwest of Pitman Grove, and a short steamboat trip from Philadelphia. ${ }^{75}$ In 1922, Rev. S. Lewis Adams's Glassboro Holiness Camp, affiliated with the Pilgrim Holiness Church, offered a ready supply of family tents, a boardinghouse, and preachers from as far away as Kentucky and Indiana. ${ }^{76}$ By 1931 , holiness advocates established Fletcher Grove in Delanco and a holiness camp in Aura. ${ }^{77}$

\footnotetext{
72 William Warren Sweet, Revivalism in America (New York: Charles Scribner's Sons, 1945), xiii, 164.

${ }^{73}$ William McLoughlin, Revivals, Awakenings, and Reform (Chicago, IL: University of Chicago Press, 1977), 347350 .

${ }^{74}$ Holiness advocacy was a subculture in mid-century Methodism of believers who embraced John Wesley's notion of entire sanctification or a post-conversion outpouring of grace in which a believer experiences perfect love and is empowered to resist sin. The Association's second and third presidents-Rev. Jacob Graw, a popular preacher and temperance advocate elected in 1872, and Rev Aaron Ballard, a founding member of Ocean Grove who, after succeeding Graw in 1875, led the Association until he died in 1916-welcomed holiness advocates with prayer meeting tents for testimonies of sanctification and services for the promotion of holiness. For an overview of the Wesleyan holiness movement, see Melvin Dieter, The Holiness Revival of the Nineteenth Century (Lanham: Scarecrow Press, 1996). For discussions of holiness and holiness activities at Pitman Grove, see Ballard, "A Letter from Dr. Ballard"; see also NJCCMA Minutes for 1873 to 1877.

75 Parker, Pitman Grove, 103-104; “A Great Auditorium,” The Morning Post, August 17, 1895, 1.

76 “Annual Holiness Camp Meeting," Pitman Grove Review, July 27, 1932, 2; see also Wilson, 132.

${ }^{77}$ Gail Eisenlohr, “The Changing Camp Meeting in Southern New Jersey,” Master's thesis (Rowan University 1970).
} 
Shifting revivalist culture and competition from holiness camp meetings occurred during a transformation in New Jersey's resort industry. When Methodists established camp meeting resorts, they did so at the cusp of the state's nineteenth-century vacationing boom. Camp meeting resorts benefitted as much as secular resorts from a rising tide of vacationers through the 1890s, but the geography of vacationing practices in South Jersey would shift by the twentieth century. Through the 1890s, vacationing Philadelphians could choose from excursion resorts along the Delaware estuary, including large amusement parks such as Washington Park in Westville and Riverview Beach in Pennsville. ${ }^{78}$ Many of these resorts advertised as "family friendly" destinations for vacationers wanting a degree of morality in their leisure but not necessarily the severity of Methodist rules against card-playing, dancing, and drinking. However, by the 1920s, aided by express trains and growing automobile ownership, the thrust of South Jersey vacationing shifted well past Pitman to the Jersey Shore. Even the Review succumbed to running advertisements for summer homes at the shore and discount rates for shore resort hotels.

By 1924, as Pitman's status as a vacation destination receded, Rev. E. L. Hyle, the new president of the Association, took steps to reverse declining attendance. Hyle looked for help from Rev. Harold Paul Sloan of Haddonfield, the leader of Methodism's small but vocal fundamentalist movement. ${ }^{79}$ Although the Methodist Episcopal Church did not face the same degree of fundamentalist controversies over modernism, higher biblical criticism, and evolution (which roiled northern Baptists and Presbyterians), Delaware, Eastern Pennsylvania, and South Jersey were a Methodist fundamentalist hotbed. ${ }^{80}$

\footnotetext{
${ }^{78}$ Samuel Avery-Quinn, "Sea Breeze: A Landscape History," SoJourn: A Journal Devoted to the History, Culture, and Geography of South Jersey 4, no. 2 (Winter 2020/2021): 21-36.

${ }^{79}$ Floyd Cunningham, "Harold Paul Sloan and Methodist Essentialism," The Asbury Journal 42, no. 1 (1987): 65-76.

${ }^{80}$ William Warren Sweet, Methodism in American History, Revised edition (Nashville: Abingdon Press, 1954$), 392$.
} 
Sloan invited well-known members of his fundamentalist network to headline revivals at Pitman Grove, forming the cadre of "great evangelists" that Helen Wood remembered years later. Leading the list in 1925 was Rev. Henry Clay Morrison, editor of the Pentecostal Herald and president of Asbury Theological Seminary in Wilmore, Kentucky. ${ }^{81}$ Morrison was a talented orator who brought his assault on evolution and modernism to a packed auditorium at Pitman Grove. ${ }^{82}$ The following year, the Association arranged for Rev. Paul Rader of Chicago to preach for several days. ${ }^{83}$ From July 22, 1925, through the camp meeting's close, the former Methodist minister, prizefighter, and oil speculator delivered missives against lukewarm faith and Christians straying from Gospel truths. In his opening sermon, with rain falling outside the auditorium and beads of sweat on his brow, Rader crouched and thrust his fists into the air in a pantomime fight with the devil, modernists, professors of evolution, and parents who "sissified their boys." Among his attentive listeners, one Camden reporter was uncertain if the devils Rader fought included the large gathering of the Ku Klux Klan 500 yards away on Broadway. ${ }^{84}$

In the 1920s, support for the second Ku Klux Klan was widespread among New Jersey's whites. ${ }^{85}$ Klan rallies and parades were common through the decade. Despite Methodist Bishop Joseph Berry's vehement disapproval, South Jersey Methodist churches and camp meeting

\footnotetext{
${ }^{81}$ For a biography of Morrison, see Percival Wesche, Henry Clay Morrison: Crusader Saint (Berne, IN: Herald Press, 1963). For discussion of Morrison's missives against evolution and modernism, see Ronald Numbers, "Creation, Evolution, and Holy Ghost Religion: Holiness and Pentecostal Responses to Darwinism," Religion and American Culture: A Journal of Interpretation 2, no. 2 (Summer 1992): 127-158.

82 "Fifty-Fourth Pitman Grove Camp One of Biggest and Best in Many Years," Pitman Grove Review, August 7, 1924, 1.

${ }^{83}$ For Rader, see Larry Eskridge, "Only Believe: Paul Rader and the Chicago Gospel Tabernacle, 1922-1933," Master's thesis (University of Maryland, 1985). For Rader's later pioneering work in radio, see Tona Hangen, Redeeming the Dial: Radio, Religion, and Popular Culture in America (Chapel Hill: University of North Carolina Press, 2002), 37-48. Newspaper articles covering Rader's visit to Pitman included "Parents Scolded for Their Lollypopping," The Morning Post, July 24, 1925, 1.

84 “Camp Meeting, Ku Klux Klan, Dance, Vaudeville, at Pitman,” The Morning Post, July 23, $1925,4$.

${ }^{85}$ Linda Gordon, The Second Coming of the KKK (New York: Liverlight Publishing, 2017); Joseph Bilby and Harry Ziegler, The Rise and Fall of the Ku Klux Klan in New Jersey (Charleston: History Press, 2019).
} 
communities had significant ties to the Klan. ${ }^{86}$ By 1925, the Gloucester County chapter of the Klan claimed to have 4,000 members and sent representatives to speak at Methodist churches in Sewell, Turnersville, and Woodbury. ${ }^{87}$ Between 1923 and 1928, despite opposition from long-serving mayor J. M. McCowan, the Klan held at least four gatherings in Pitman, including a July 1924 meeting in Borough Hall. ${ }^{88}$ The Klan also found Alcyon Park a welcoming space. In 1924 and 1925, the Klan held large rallies at the park, with the former rally drawing thousands of participants from Delaware, New Jersey, and Pennsylvania. Pitman's support for the Klan seemed an outgrowth of the nativist "100 percent American" movement and post-World War I assertions of white supremacy. However, accounts of the Klan's activities in Pitman are vague as to whether the gatherings targeted specific local minority communities - since the late nineteenth century, South Jersey was home to several Jewish immigrant settlements, about 80 Catholic families lived in nearby Glassboro, and, by the late 1910s, Black realty companies in Camden and Philadelphia advertised building lots in the Elsmere neighborhood of Glassboro. ${ }^{89}$ At the time of the rallies, over 80 percent of Pitman residents were native-born whites. Less than 1 percent of the population was non-white, with the community's only African American families living between Lambs Road, Muriel Avenue, and Elwood Avenue on Pitman's northeast edge. ${ }^{90}$ For these families and other minorities in the area, the Klan's gatherings in Pitman represented the degree to which

\footnotetext{
86 "Bishop Berry Warns Pastors Against Klan," The Evening News (Wilkes-Barre, PA), January 2, 1924, 5; see also Kelly Baker, Gospel According to the Klan: The KKK's Appeal to Protestant America, 1915-1930 (Lawrence: University Press of Kansas, 2017).

${ }^{87}$ Robert Tucker, The History of Elsmere: African American Life in Glassboro, New Jersey (Bloomington: Archway Publishing, 2019), 69-71.

88 “Klan Auxiliary Plans Field Day at Pitman," Courier-Post, September 8, 1928, 4; “20,000 Klansmen In Pitman Meet," Courier-Post, June 2, 1925, 16; "Reformed Klan Hears Commander," The Morning Post, July 22, 1924, 2; "Pitman All Stirred as Klan Gathers in Woods," The Morning Post, May 27, 1924, 1.

89 Tucker, 10-12, 73; Ellen Eisenberg, Jewish Agricultural Colonies in New Jersey, 1882-1920 (Syracuse University Press, 1995); William Stainsby, The Jewish Colonies of South Jersey (Camden: S. Chew and Sons, 1901).

901920 U.S. Census, Pitman, Gloucester County, New Jersey; Population Schedule; Roll T625_1027; Enumeration District 152.
} 
whiteness defined the suburban community's majoritarian identity. Few may have been surprised when, in 1928, the Association invited William "Billy" Sunday, a revivalist with well-known affinities for white nationalism, to be the revival's headline preacher. ${ }^{91}$

When Billy Sunday arrived in Pitman on August 6, 1928, he told a gaggle of reporters that "next to the South, Southern New Jersey and Eastern Pennsylvania have the greatest religious feeling in the country." ${ }^{92}$ The former Chicago White Stockings outfielder turned evangelist had been a household name. However, like the aging cottagers of Pitman Grove, the 66-year-old Sunday was not the entertainer he used to be-his gyrations were slower, his leaps and bounds fewer, and his celebrity diminished. As the Camden Courier-Post described Sunday that summer, he had been "America's greatest religious phenomenon," but a phenomenon that "has made few appearances, in late years, in the larger cities. ${ }^{.93}$ For two days in Pitman, Sunday held 4,000 attendees in rapt attention. ${ }^{94}$ The Association considered Sunday's visit such a success that they invited him back in 1929 and again in 1930. When Billy Sunday left Pitman Grove in August 1930, he was the last of the "great evangelists" to preach in the Grove.

\section{Urban Renewal}

Soon after Billy Sunday's departure, in the throes of the Great Depression, summer worship and residence continued in Pitman Grove, but changes in both were noticeable. The annual camp meeting faced such declining attendance that by 1933, an editorial in the Woodbury Times doubted

\footnotetext{
${ }^{91}$ For Sunday's biography and revivalist career, see Lyle Dorsett, Billy Sunday and the Redemption of America (Macon, GA: Mercer University Press, 2004); Roger Bruns, Preacher: Billy Sunday and Big-Time American Evangelism (Urbana: University of Illinois Press, 2002).

92 "Billy Sunday Ready for Foe," The Morning Post, August 7, 1928, 4.

93 "Sunday's Recent Revivals Confined to Small Towns," Courier-Post, August 6, 1928, 8.

94 "Big Pitman Crowd Hears Billy Sunday," Courier-Post, August 6, 1928, 8. For Sunday's subsequent visits to Pitman Grove, see "Pitman Meetings End with Concert," The Morning Post, August 6, 1930, 21; "Billy Sunday Tells Pitman Campers It's Hard to Be Good Now," The Morning Post, August 5, 1930, 3; "Billy Sunday Flays Wets at Pitman Grove Camp Sermons," The Daily Journal (Vineland, NJ), August 5, 1930, 1; "Jazz, Whoopee Age Blamed by Sunday For Church Losses," Courier-Post, August 5, 1929, 3. See also Wilson, 132-133.
} 
the camp meeting would continue much longer. ${ }^{95}$ The Camden Evening Courier noted that "rumors ... have cropped up repeatedly in recent years that the summer meetings might be abandoned." 96 Although the Review continued to publish lists of cottagers arriving for the summer season, those lists were dwindling. About one-third of Camden and Philadelphia families who owned a Pitman Grove cottage in the 1920 s sold their cottages by $1940 .{ }^{97}$ Many of their buyers became year-round residents, while other Pitman residents bought at least 40 cottages for use as rental properties. In November 1938, the Association informed Borough Council that they would discontinue providing streetlights, garbage collection, and the maintenance of stormwater sewers in the Grove. ${ }^{98}$

However, Pitman's economic fortunes, like suburban communities across the country, improved dramatically in the postwar years. ${ }^{99}$ The federal government, through the Federal Housing Administration, the Home Owners Loan Corporation, and the Veterans Administration, significantly boosted the suburban housing market. ${ }^{100}$ However, lending criteria that favored new construction over renovating old houses contributed to a surge of disinvestment in center cities.

\footnotetext{
95 Wilson, 154-157.

96 "Camp Meeting Dates Set at Pitman Grove," Evening Courier (Camden, NJ), January 28, 1939, 2.

${ }^{97}$ For cottages within the wagon wheel, the Association retained control of the land while buyers and sellers exchanged the cottage itself. Without deeds changing hands, and Gloucester County records for large, taxable personal property transfers are incomplete. This assessment is based on available personal property transfers and borough directories.

98 "Camp Meeting Ends Its Self-Service," Courier-Post, November 16, 1938, 15. The Grove was not alone in facing declining revenues through the Depression and World War II. Most notably, following George Carr's death in 1935, was the decline of Alcyon Park. While the amusement park navigated the Depression with dwindling crowds, reduced staff, and some amenities shuttered, the war years were particularly challenging for South Jersey's resort industry. By 1945, the Borough acquired and sold Alcyon Park and the Alcyon Racetrack at a tax auction, while turning over the lake's improved beach to the Kiwanis Club to run as a public bathing ground. "Pitman to Auction Race Track for Tax," Evening Courier, October 15, 1940, 3; see also Wilson, 92.

99 Wilson, 102.

${ }^{100}$ In tandem, these three federal agencies ensured residential mortgages and refinanced defaulted mortgages, and, further, the Veterans Administration offered returning soldiers low-interest loans. For work on how these agencies enforced racial segregation in housing, see Paige Glotzer, How the Suburbs Were Segregated: Developers and the Business of Exclusionary Housing, 1890-1960 (New York: Columbia University Press, 2020); Hanlon et al., 42-50; Freund, Colored Property; Teaford, 30-34; John Bauman, Roger Biles, and Kristin Szylvian, eds., From Tenements to the Taylor Homes: In Search of an Urban Housing Policy in Twentieth-Century America (University Park: The Pennsylvania State University Press, 2000).
} 
Criteria meant to assess mortgage risk redlined or precluded low-income families and people of color from qualifying for most mortgages. At the same time, corporate offices, manufacturers, and retail businesses followed their shifting customer and employee bases to the suburbs. Near Pitman, industries spilled down the Delaware River with shipbuilding, Texaco and Sacony-Vacuum oil refineries, a Rohm and Haas chemical plant, as well as plants for DuPont and Columbia Records. For mid-level managers and skilled blue-collar workers at these plants, Pitman was an attractive bedroom community. ${ }^{101}$ A wave of new residents boosted Pitman's population from 5,507 in 1940 to 6,960 in $1950 .{ }^{102}$ By 1960 , the population had swelled to 8,644. As housing pressures increased in Pitman, some landowners turned older houses in and near the Grove into rental properties for the influx of workers and the growing number of students at nearby Glassboro State Teachers College (now Rowan University).

In 1952, facing population growth, housing problems, and snarled traffic in the Broadway central business district, Borough Council, which had for decades functioned as a planning organization, established a planning board. ${ }^{103}$ In the first month of the board's operation, Chairman Eugene Eipper collected master plans from other New Jersey towns, recommended board members attend planning conferences, and reached out to the Fels Institute at the University of Pennsylvania - a program for planning professionals that offered a Government Consulting

\footnotetext{
${ }^{101}$ Unfortunately for the health of Pitman residents, the community was also an attractive location for industrial waste. Just outside the borough, in Mantua Township, Nicholas Lipari turned an abandoned marl and gravel pit into a dump for several factories that located in the Pitman area during the postwar years. Between 1958 and 1971, the site accepted an estimated 2.7 million gallons of industrial waste. The chemicals seeped into Pitman's groundwater and Alcyon Lake. In the 1980s, the U.S. Department of Environmental Protection declared the former landfill and surrounding properties a superfund site and began remediation efforts through the 1990s. See "Cleanup Is Set at Jersey Dump, the Nation's Worst," New York Times, September 27, 1987, 58.

102 Wilson, 160. In February 1955, Harold Wilson, working with the Philadelphia Regional Port Authority, conducted a survey of Pitman residents. Among his findings, between 75 and 90 percent of residents living in recently built houses in the borough commuted to work in Camden, factories along the Delaware River, or other suburban towns in Camden, Cumberland, and Gloucester Counties - see Wilson, 160-162.

${ }^{103}$ Borough of Pitman Planning Board Minutes, May 18, 1952. On file, Borough of Pitman Construction Office, Pitman, New Jersey.
} 
Service (GCS) for state and local governments. ${ }^{104}$ By July 1952, Charles Cella of GCS began work with Eipper to walk board members through the basics of planning. ${ }^{105}$ For the next three years, GCS staff provided the board with reports and projections on the borough's land use, population, housing, and transportation needs. In 1955, Cella worked with the board on drafting a comprehensive master plan, a process Cella's successor, Anshel Melamed, would help the board complete in $1959 .{ }^{106}$ The master plan offered projections for the borough through 1980 , including estimating population growth to about 12,000 residents, a housing shortage by the 1970 s and pressure to convert older houses into multi-unit properties, the need for additional commercial space, alleviating traffic congestion on Broadway, expanding parking facilities around the business district, and addressing the decline of the Grove. ${ }^{107}$

The master plan described the Grove's cottages as substandard housing. The Grove's wagon wheel was a "jumble of lot layout" with inadequate access for vehicle traffic and parking, and the close massing of cottages presented a fire hazard. ${ }^{108}$ Relying on a 1958 survey of Grove housing conducted by GCS, the Planning Board reported that of the 244 cottages in the Grove, 83 (or 34 percent) were substandard, but, paradoxically, the master plan claimed that "in the Grove

\footnotetext{
104 The Fels Institute provided planning assistance for communities throughout the Delaware Valley. The extent of their work in the 1950s helping municipalities prepare comprehensive master plans, as well as their role in urban renewal projects in the region, is uncertain, as the Institute's records are not available to the public. For more on the Institute, see Steven J. Diner, Universities and Their Cities: Urban Higher Education in America (Baltimore, MD: Johns Hopkins University Press, 2017), 81. See also, Government Consulting Service, "Planning Report for Woodbury, NJ," unpublished manuscript, 1953, Gloucester County Historical Society, Woodbury, NJ.

${ }^{105}$ Planning Board Minutes, September 20, 1955.

${ }^{106}$ Comprehensive master plans were long a staple of professional planning in Europe and the United States. Although such influential books as Kevin Lynch's Site Planning (1962) continued a tradition of plans that emphasized visions for the harmony of a city's overall design, by the late 1950s planners were less concerned with the complex unity of a city than they were concerned with plans that shaped the governance of local land use. See Jon Peterson, The Birth of City Planning in the United States, 1840-1917 (Baltimore: The Johns Hopkins University Press, 2003); Michael Neuman, “Does planning need the plan?” Journal of the American Planning Association 64, no. 2 (Spring 1998): 208220; Kevin Lynch and Gary Hack, Site Planning, Third Edition (Cambridge: MIT Press, 1994); Stuart Chapin, Jr., Urban Land Use Planning (Urbana: University of Illinois Press, 1957).

${ }^{107}$ Preliminary Comprehensive Plan for the Borough of Pitman, Gloucester County, New Jersey. Borough of Pitman Planning Board, Pitman, NJ, 1957.

${ }^{108}$ Preliminary Comprehensive Plan, 13-14.
} 
section, no amount of improvement . . can undo the decline," and that "redevelopment of this area will someday be necessary and the project will require financial assistance from the state and federal government."109 The plan suggested that a redeveloped Grove could serve a variety of purposes such as apartment complexes, a parking lot for the downtown business district, even "an expanded borough hall, a heliport, and additional stores . .."110 The plan cautioned, however, that "even with outside aid . . practical difficulties will remain since ... many of the residents probably have a strong attachment to it."111

Although Pitman may have seemed an unlikely municipality to pursue a federally funded urban renewal program, the American "culture of clearance" was widespread in municipalities large and small in the 1950s and 1960s. ${ }^{112}$ The federal urban renewal program was established through Title 1 of the Housing Act of 1949, amended by the Housing Act of 1954, and boosted by the passage of the Interstate Highway Act of $1956 .{ }^{113}$ The intention of the legislation's renewal program was to bolster declining urban land values through the demolition of areas designated as "blighted." Although government intervention in the urban real estate market occurred in tandem

${ }^{109}$ Preliminary Comprehensive Plan, 14. As David Schuyler notes, notions of cities as organic entities with life cycles were common in twentieth-century urban planning. That disinvestment in a neighborhood was a process inevitably leading to further decay formed the basis for arguments in favor of urban renewal even if the buildings in the neighborhood did not, at the time, meet all the criteria for "blight," as blight seemed an inevitable outcome. See Schuyler, 29; Neil Smith, Paul Caris, and Elvin Wyly, "The 'Camden Syndrome' and the Menace of Suburban Decline: Residential Disinvestment and Its Discontents in Camden County, New Jersey," Urban Affairs Review 36, no. 4 (2001): 497-531.

${ }^{110}$ Ibid.

111 Ibid.

112 The literature on urban renewal is vast with scholars turning a critical eye to the practice as early as the 1960s. For early work on urban renewal, see Martin Anderson, The Federal Bulldozer (Cambridge: M.I.T. Press, 1967); James Q. Wilson, ed., Urban Renewal: The Record and the Controversy (Cambridge: The M.I.T. Press, 1966); Jane Jacobs, The Death and Life of Great American Cities (New York: Random House, 1961). For general works on the history of urban renewal, see Robert Fogelson, Downtown: Its Rise and Fall, 1880-1950 (New Haven: Yale University Press, 2001); John Teaford, The Rough Road to Renaissance: Urban Revitalization in America, 1940-1985 (Baltimore: The Johns Hopkins University Press, 1990). For an interrogation of America's mid-century "culture of clearance" via the lens of the bulldozer as an instrument of progress, see Francesca Russello Ammon, Bulldozer: Demolition and Clearance of the Postwar Landscape (New Haven: Yale University Press, 2016).

113 Ashley Foard and Hilbert Fefferman, "Federal Urban Renewal Legislation," in James Q. Wilson, ed., Urban Renewal: The Record and the Controversy (Cambridge: The M.I.T. Press, 1966), 71-125. 
with veterans housing assistance, mortgage guarantees, and other programs to promote new housing, critics of the renewal program were quick to note that nothing in the legislation required that demolished housing be replaced with new housing, and that, by the 1960s, the program disproportionately impacted minority communities. ${ }^{114}$ By 1968, cities and towns across the country launched at least 2,100 redevelopment projects. ${ }^{115}$ Although the federal government provided two-thirds of redevelopment costs, decisions over what areas of a municipality were blighted, the parameters of a renewal project, and outcomes were eminently local decisions often driven by pro-growth coalitions of politicians and business groups. ${ }^{116}$

In November 1963, as New Jersey was becoming one of the densest metropolitan areas in the country, the Public Service Electric and Gas Company (PSE\&G), advertised the state as "a leader in urban renewal" with active projects in 68 communities that were "all geared to making our state a better place to live and work ... thanks to New Jersey's keen planning for the future through urban renewal." 117 Through the 1950s, municipalities throughout the state hired planning consultants to help develop comprehensive master plans, revised residential building codes, surveyed housing conditions, and considered ways of reconfiguring their central business districts

\footnotetext{
${ }^{114}$ See John Short, Alabaster Cities (Syracuse University Press, 2006); Jon Teaford, "Urban Renewal and Its Aftermath," Housing Policy Debate 11, no. 2 (2000): 443-465.

115 Although large cities from New York to Los Angeles undertook the highest profile and largest-scale urban renewal projects, by the end of the federal urban renewal program in 1973, the program had a significant impact on midsized cities and small towns. For instance, in 1954, Clarksville, Tennessee (population 16,246), was one of the first municipalities in the country to apply for federal urban renewal funding, and, through the 1960s, New Haven, Connecticut (population 152,000), received the most federal urban renewal dollars per capita of any municipality. See Mandi Jackson, Model City Blues: Urban Space and Organized Resistance in New Haven (Philadelphia: Temple University Press, 2008); Clarence Stone and Heywood Sanders, "Reexamining a Classic Case of Development Politics: New Haven, Connecticut," in Clarence Stone and Heywood Sanders, eds., The Politics of Urban Development (Lawrence: University Press of Kansas, 1987); "Small Tenn. City First In Fight Upon Slums," Courier-Post, December 9, 1954, 1. For case studies of urban renewal in small to midsized cities, see David Schuyler, A City Transformed: Redevelopment, Race, and Suburbanization in Lancaster, Pennsylvania, 1940-1980 (State College: The Pennsylvania State University Press, 2002); Heywood Sanders, "The Politics of Development in Middle-sized Cities: Getting from New Haven to Kalamazoo," in Clarence Stone and Heywood Sanders, eds., The Politics of Urban Development (Lawrence: University Press of Kansas, 1987), 182-198. For the 2,100 projects figure, see Emily Talen, "Housing Demolition during Urban Renewal," City \& Community 13 no. 3 (2014): 233-253, 238.

${ }^{116}$ Dennis Judd and Robert Mendelson, The Politics of Urban Planning (Urbana: University of Illinois Press, 1973).

117 "New Jersey . . . is a leader in urban renewal!" [advertisement] Courier-Post, November 21, 1963, 24.
} 
to better compete with suburban strip malls. Through the 1960s, urban renewal projects in the state clustered in three areas. By the late 1950s, Hoboken, Jersey City, Newark, Patterson, and other industrial cities in North Jersey embarked on a wave of federally funded projects. ${ }^{118}$ Coastal resort communities, from Asbury Park south to Atlantic City and Wildwood, initiated projects to clear "substandard" housing and expand commercial areas. ${ }^{119}$ Along the Delaware River and in the state's southwestern counties, Camden and Trenton launched multiple urban renewal projects through the 1960 s, but so too did smaller communities. ${ }^{120}$ Older towns with declining glass or shipbuilding industries, such as Bridgeton, Glassboro, and Millville, launched clearance programs in low-income neighborhoods. ${ }^{121}$ Smaller boroughs and townships, including Clementon, Deptford, Maple Shade, and Mount Holly, having faced a postwar surge of new residents, also drew on federal funds for projects that included expanding municipal services and new housing for seniors and veterans. ${ }^{122}$

On February 9, 1959, residents packed a Borough Council meeting to learn about Pitman's urban renewal plan. That evening, Council planned to approve an ordinance creating a housing authority, a necessary step in applying for an urban renewal grant. Mayor Hal Thompson told the

\footnotetext{
${ }_{118}$ Robert Curvin, Inside Newark: Decline, Rebellion, and the Search for Transformation (New Brunswick: Rutgers University Press, 2014); Robert Weaver, The Urban Complex (New York: Doubleday, 1964); Harold Kaplan, Urban Renewal Politics: Slum Clearance in Newark (New York: Columbia University Press, 1963). Beginning in the mid1950s, area newspapers were replete with accounts of planned, active, and failed urban renewal projects in North Jersey - see particularly The Central New Jersey Home News (New Brunswick), The Evening News (Newark), The Morning Call (Paterson), and The Record (Hackensack, NJ).

${ }^{119}$ See, for instance, "Urban Project OK'd For Sea Isle City," Courier-Post, January 20, 1966, 8; "\$95,850 Grant For Growth Plan To Ocean City," The Daily Journal, April 13, 1962, 3; "3 N.J. Municipalities Get Renewal Funds," Courier-Post, July 9, 1959, 7; "Long Branch to Get U.S. Renewal Funds," Courier-Post, June 16, 1959, 14; "Proposed Asbury Park Housing Project," Asbury Park Press, September 1, 1956, 2.

${ }^{120}$ See Howard Gillette, Jr., Camden After the Fall: Decline and Renewal in a Post-Industrial city (Philadelphia: University of Pennsylvania Press, 2005); "Trenton Seeks Urban Aid Funds," Courier-Post, March 3, 1958, 2.

${ }^{121}$ See "Millville Awarded \$37,000 Grant," The Daily Journal, January 24, 1964, 2; "Bridgeton Granted Urban Renewal Aid," The Daily Journal, March 6, 1963, 1; "Urban Renewal Plan Pushed at Glassboro," Courier-Post, February 16, 1961, 18.

${ }^{122}$ See "Maple Shade Is Undergoing The Pains of Urban Renewal," Courier-Post, November 27, 1968, 9; "Clementon Aid \$718,524 For Urban Renewal," Courier-Post, April 19, 1968, 8; "Urban Renewal Plan Voted for Mt. Holly," Courier-Post, April 17, 1959, 4.
} 
crowd about the borough's determination that the Grove was a blighted area and outlined a plan for the redevelopment of the western third of the Grove, the side nearest the downtown businesses along Broadway, and a separate plan to upgrade the stormwater system in the Grove and the downtown business district. ${ }^{123}$ He estimated that the plan would cost the borough $\$ 83,000$ plus a grant of $\$ 285,000$ from the federal government - upgrading the stormwater system would be a separate expense and could cost up to $\$ 200,000$.

When Thompson opened the floor for questions, the concerns residents expressed as much as what they did not revealed how the sense of place in Pitman Grove had changed since the 1920s. When William Mollenhauer, a retired U.S. Forest Service employee and co-owner, with his wife Lorraine, of rental properties in the Grove, spoke, he claimed that the Planning Board intended "to wipe out the Grove."124 The economics of relocating Grove residents, he argued, did not make sense. How could anyone living in the Grove, where 84 percent of residents had annual incomes of less than $\$ 5,000$, afford another house or qualify for a mortgage when their equity was a house worth $\$ 3,000$ at best? ${ }^{125}$ Not once, however, did anyone express surprise that the Camp Meeting

\footnotetext{
${ }^{123}$ Minutes of Borough Council, Borough of Pitman, Gloucester County, N. J., February 9, 1959. On file, Borough of Pitman, Office of the Borough Clerk, Pitman, New Jersey.

${ }^{124}$ Minutes of Borough Council, February 9, 1959, 23. Mollenhauer's concern, like many of the concerns raised in discussions of the redevelopment of the Grove, was for cottagers and property owners, not so much for renters. Comparing deeds and available lists of cottagers with Pitman directories and telephone books suggests that at the time, cottagers and property owners accounted for at least 60 to 70 percent of Grove properties. Details on the identity of renters is unavailable. However, the author's conversations with longtime Pitman residents suggest that the Grove's cottages were, at the time, occupied entirely by white residents. Through the 1960s, Pitman's African American residents continued to live in the northeastern section of the borough, between Lambs Road and Elwood Avenue. In a 2018 interview, former New Jersey Supreme Court Associate Justice John Wallace Jr. (b. 1942), reflected on growing up in Pitman as one of the community's few African American residents. The Wallace family moved to Pitman in the 1930s. His father owned Pitman Dry Cleaners and was co-owner of a taproom in Glassboro. Wallace described the houses of other African Americans in the borough as clustered near his family's house on Muriel Avenue. See Shaun Illingworth, "Interview with Justice John E. Wallace, Jr.," Rutgers Oral History Archives, April 18, 2018. https://www.njcourts.gov/courts/assets/images/archives/oralhist/wallacetranscript.pdf?c=q3C, accessed January $15,2021$.

${ }^{125}$ Although federal urban renewal guidelines provided for displaced residents to receive reimbursements for moving expenses and property loss beyond the fair market value of their property, often the money allocated for such purposes represented a small fraction of any project's total funds and, across the United States, many displaced residents did not receive any reimbursements. As John Short notes, relocation funds were typically only 0.5 percent of a total
} 
Association was teetering on the edge of bankruptcy. Attendees argued against redevelopment as a threat to the Grove's low-income residents, not as a threat to the Grove as a heritage site, much less as a sacred space. Throughout the process, the only area of the Grove that retained a quality of sacred space was the auditorium. ${ }^{126}$

Over the next two years, Council, the Planning Board, and the Association worked out details of the redevelopment. With the promise of $\$ 100,000$ from an urban renewal grant for the purchase of the western third of their grounds, combined with additional not-yet-determined private financing, the Association proposed renovating the auditorium and replacing cottages with garden apartments for elderly residents. ${ }^{127}$ In May 1961, Council approved an application for $\$ 260,000$ in federal urban renewal funds, leaving the borough to pay $\$ 83,000$, financed through a 20-year bond issue. ${ }^{128}$ In February 1962, after receiving a $\$ 30,000$ planning advance grant from the federal government, Council established the Pitman Urban Renewal Agency (PURA) to manage the project. ${ }^{129}$ Council, the Planning Board, and PURA then worked for months on the site design, plans for relocating residents, and appraisal of properties in the redevelopment area.

budget. Further, in Martin Anderson's critique of urban renewal, he claims that as of 1961, only half of displaced residents had received any relocation payments. See Short, 24-25; Anderson, 57.

126 Throughout the early 1960s push for urban renewal, as well as the borough's renewed efforts in the early 1970s, the status of the auditorium was a separate question from the surrounding cottages. Both the borough and the Association saw the auditorium as a community worship space that should, if possible, remain in use. However, when the Association sold their property to the borough in 1970, they stipulated that if the demolition of the auditorium was unavoidable, the borough would have to build a new community worship space elsewhere in Pitman. See Gloucester County Deed Book 1194: 1-101.

127 Planning Board Minutes, January 16, 1961; Planning Board Minutes, January 19, 1960; "Pitman Grove Plans to Be Discussed," Courier-Post, January 18, 1960, 2.

${ }^{128}$ The borough's request for matching federal funds received preliminary approval from Housing and Home Finance Agency Administrator Robert Weaver in July 1961. See "U.S. Agency Approves Pitman Renewal Plan," CourierPost, August 1, 1961, 30.

${ }^{129}$ Minutes of Borough Council, February 12, 1962; Minutes of Borough Council, September 25, 1961. Federal urban renewal guidelines were flexible regarding what local agency was responsible for a renewal project. Whether establishing a new Local Public Agency (LPA) or vesting an already existing municipal housing agency with responsibility for redevelopment meant that a city or borough council, while retaining final authority over major actions in the renewal process, did not have to sort out every detail of the project. For procedural issues in oversight of an urban renewal project, see Carl Lindbloom and Morton Farrah, The Citizen's Guide to Urban Renewal, Revised Edition (West Trenton: Chandler-Davis Publishing, 1970). 
However, by the time PURA released a report detailing the plans, Council, after months of growing opposition from Pitman residents, voted to make approval for the project a referendum question

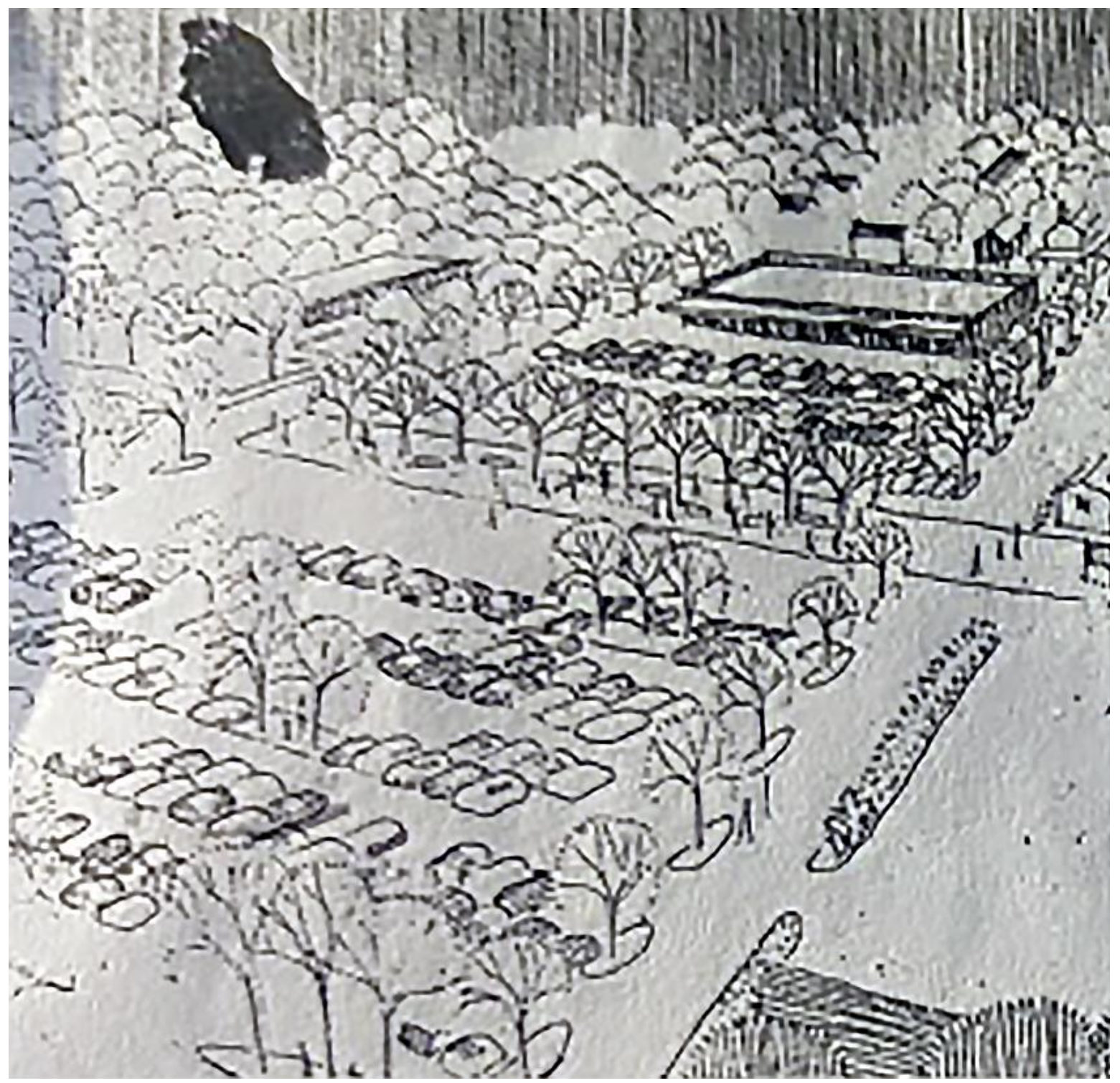

Pitman Urban Renewal Agency sketch of Pitman Grove commercial redevelopment. Sketch shows municipal parking lot (bottom), pedestrian mall (center), and proposed grocery store (top). ${ }^{130}$

on the November ballot. Their action left PURA director Howard Leroy Davis mere months to sell the community on the plan.

${ }_{130}$ Pitman Urban Renewal Agency (PURA), "Urban Renewal: The Facts for the voters," [insert], Pitman Grove Review, November 2, 1962. 
Davis hurried to address civic groups and the Pitman Businessmen's Association, and give interviews to area newspapers. ${ }^{131}$ The plan Davis pitched called for demolishing 75 cottages on 4.7 acres. On the south end of the site, the borough would build a municipal parking lot, a muchneeded feature for the business district that had seen declining sales for several years. On the north end of the site, plans called for a supermarket, perhaps an A\&P, giving Pitman residents a local option for groceries rather than driving to Glassboro. ${ }^{132}$

That November, despite Davis's efforts and the support of Council, the Planning Board, and the Association, voters rejected urban renewal by 2,593 opposed to 1,078 in favor. ${ }^{133}$ Costs, as much as if not more than emotional attachment to the Grove, defeated the measure. In the ballot question, the borough asked voters to approve $\$ 95,000$ as the borough's share of the renewal project, plus \$150,000 for “storm sewage lines and other capital improvements." Approval would have meant a 21 -cent increase in the property tax rate. ${ }^{134}$ Voters' rejection ended the project, shuttered the PURA, and left the Planning Board despondently discussing "the future role and effectiveness of the Planning Board as a local planning body."135 The following January, Councilman Claude Meyers complained that residents did not have enough time for "the absorption of this highly complex proposal" before the election. ${ }^{136}$ Planning was, he opined, "not popular."

Planning, or more precisely urban renewal, may not have been popular in Pitman, but borough authorities remained interested in the Grove's redevelopment. Three years after the

\footnotetext{
131 “Urban Renewal Before Pitman Voters on November Ballot," Courier-Post, October 13, $1962,3$.

132 Planning Board Minutes, July 16, 1962; "Pitman to Vote on Renewal Project Nov. 6," The Philadelphia Inquirer, October 15, 1962, 2.

133 "Pitman Abandons Renewal," Courier-Post, November 13, 1962, 3.

${ }^{134}$ Planning Board Minutes, September 17, 1962; "Renewal Question on Pitman Ballot," Courier-Post, November 5, 1962, 1.

135 Planning Board Minutes, November 19, 1962.

${ }^{136}$ Minutes of Borough Council, January 7, 1963.
} 
measure's defeat, the Association asked the Planning Board for an exemption to the borough's 1953 residential zoning ordinance. ${ }^{137}$ Seeking to boost their flagging finances, the camp meeting managers wanted to sell cottagers the Association-owned land beneath their homes. However, the lots were smaller than the minimum size borough zoning allowed for residential parcels. ${ }^{138}$ Owning a cottage without owning the land beneath it meant that cottage owners could not secure a mortgage, and elderly owners did not qualify for the state's homestead tax rebate. ${ }^{139}$ Although the Board, at first, was sympathetic, they denied the request. With their request rejected, the Association sued the borough and the Planning Board. In 1967, a state court in Woodbury ruled in the Association's favor. ${ }^{140}$ Over the next two years, the Association sold 37 lots across their remaining grounds. By the end of the decade, the sales, combined with the borough's purchase of the decaying Lizzie Smith Temple and properties once owned by the defunct Cottagers' Association, left the Grove a patchwork of property ownership that seemed set to stymie future redevelopment. ${ }^{141}$

\footnotetext{
${ }^{137}$ Planning Board Minutes, November 19, 1962.

${ }^{138}$ As much as zoning ordinances were a means of managing land use, they were also a means of maintaining property values. In predominantly white suburban communities, this meant an emphasis on single-family homes on sizable lots. This emphasis was an exclusionary, gatekeeping practice that either severely limited the availability of affordable, multiunit housing or relegated such housing to less-desirable areas of a community. Such exclusionary residential zoning practices that prohibited multiunit housing and mobile homes were common in South Jersey. Of note, in 1975, the New Jersey Supreme Court, in a landmark ruling, sided with plaintiffs who had sued the township of Mount Laurel over that Burlington County community's exclusionary zoning ordinances. See David Freund, Colored Property; Gerald Frug, "The Legal Technology of Exclusion in Metropolitan America," in Kevin Kruse and Thomas Sugrue, eds., The New Suburban History (University of Chicago Press, 2006), 205-219. For the Mount Laurel decision, see David Kirp, John Dwyer, and Larry Rosenthal, Our Town: Race, Housing, and the Soul of Suburbia (New Brunswick: Rutgers University Press, 1997); Southern Burlington County N.A.A.C.P. v. Mount Laurel, 67 N.J. 151 ; 336 A.2d713 (1975).

139 “N.J. Conference Camp Meeting Assoc. Appeal to Planning Board,” Pitman Grove Review, July 22, $1961,1$.

${ }^{140}$ New Jersey Conference Camp Meeting Association v. Borough of Pitman, New Jersey Superior Court, Docket no. 1-27586-65 PW (1967); see Harold Wilson and Lorraine Mollenhauer, A History of Pitman New Jersey (Pitman: printed by the author, 1976), 179-180.

${ }^{141}$ Built in 1896 to hold prayer meetings and smaller group worship services, the wooden pavilion was named after holiness evangelist Lizzie Smith. For more on Smith and the Temple, see Wilson, 22; see also Lizzie Smith, "Experience of Mrs. Lizzie R. Smith," The Holiness Advocate, September 16, 1904, 4.
} 
Despite the patchwork of property ownership in the Grove, the borough seemed locked in to a trajectory of asserting control over the Grove's development. Late in the summer of 1970, Pitman residents learned of a new effort to redevelop the Grove when borough officials mailed notices to Grover property owners announcing that the Association and borough representatives had negotiated the borough's purchase of the Grove. ${ }^{142}$ That October, Council approved the purchase-voting to spend $\$ 100,000$ for the Association's land and $\$ 50,000$ for additional properties on East and Fifth Avenues, financed through a bond issue. ${ }^{143}$ On January 1, 1971, with deeds signed and a $\$ 37,000$ down payment made to the Association, the Borough of Pitman became the owner of 317 empty lots, and landlord of 55 cottages rented from the Association and 76 privately owned cottages on land still leased from the Association. ${ }^{144}$ With the transfer complete, the Association, after paying down debts, began the process of dissolving as a nonprofit corporation.

Once again, residents packed the council chamber and public meetings of the Planning Board. Council President Andrew Gendron tried to assure residents that the borough acted with the best of intentions. The borough only purchased the Grove "to eliminate the possibility of a speculative developer buying the area and doing as he wished with it, in order to make a quick profit, without regard for people, local business, or the future of Pitman." ${ }^{145}$ Borough officials claimed they would manage the Grove "with a minimum of inconvenience" to residents, especially elderly owners. The narrative of saving the elderly from a decaying neighborhood became a

142 "Notice to Home Owners in Pitman Grove," undated letter (circa August or September 1970), Pitman Collection, Gloucester County Historical Society, Woodbury, New Jersey. For a discussion of how municipal decisions are shaped by path dependency, policy feedback, and pro-growth frameworks, see Kevin Gotham, "Growth machine up-links: Urban renewal and the rise and fall of a pro-growth coalition in a US city," Critical Sociology 26, no. 3 (2000): 268300.

${ }^{143}$ Minutes of Borough Council, October 12, 1970.

144 "Grove Sold to Pitman For \$100,000," Courier-Post, January 2, 1971, 9.

${ }^{145}$ Minutes of Borough Council, November 9, 1970. 
prominent theme in the borough's discussions and planning. ${ }^{146}$ When Council formed a committee of borough officials, Planning Board members, and Pitman residents to discuss the Grove's redevelopment, one of their foremost tasks was to address the needs of elderly Grove residents.

However, the strategy of emphasizing the plight of the elderly had two flaws that would be fatal for redeveloping the Grove. First, despite public appeals by borough officials, few elderly residents believed they needed rescue. While elderly residents were low income, many, with childhood memories of the Grove and Alcyon Lake, had deep attachments to their homes. As Joe Simone told a Philadelphia Inquirer reporter: "I don't want to be boxed in . . I don't want an apartment. We live here." ${ }^{\prime 147}$ Second, the tension of urban renewal as a rescue or as a threat to the Grove's elderly residents was a compelling media narrative. Area newspapers and television stations gave the redevelopment extensive coverage. In October 1972, the Philadelphia Inquirer began a lengthy article by relating an encounter between William Peterson, Superintendent for the Grove, and Louise Steinhauser. "Oh Bill, they're not going to tear down my place, are they? Tell me the truth now. I don't know what I'd do if they took it down," the article began, quoting Steinhauser. ${ }^{148}$ That same year, the Courier-Post covered the borough's eviction of Bertha Ladislaw, a mother with two young children who had refused to pay rent until the borough repaired her cottage. ${ }^{149}$ Other reporters interviewed elderly residents like Helen Wood, amplifying their stories and reminding the public that the Grove was a meaningful landscape.

In 1971, the borough hired Alvin E. Gershen Associates of Trenton to provide recommendations for the redevelopment of the Grove. Like the earlier GCS reports, Gershen

\footnotetext{
${ }^{146}$ For instance, in July 1972, Councilman Clinton Kandle lashed out against "profiteering landlords," many of whom, he claimed, were absentee owners charging exorbitant rent. See "Kandle Blasts 'Profiteering Landlords' Who Abuse Welfare System in Grove," The Pitman Review (Pitman, NJ), July 15, 1971, 1.

147 “Condemnation Nears Tabernacle," The Philadelphia Inquirer, April 9, 1975, 1.

148 "Pitman Grove to Clear Way for New Project," The Philadelphia Inquirer, October 29, 1972, 125.

149 "Evicted Mother of Two Still Homeless," Courier-Post, May 11, 1971, 19; "Pitman Mother of Two Is Evicted by Borough," Courier-Post, May 8, 1971, 1.
} 
Associates predicted that Pitman would face increasing population and mounting pressures for new housing through the end of the century. ${ }^{150}$ After surveying Grove properties, their report noted that vacant land "accounted for more than any other use in the study area with 6.3 acres or 36\%" and that most of the houses were in fair to poor condition and were obsolete by modern construction standards. ${ }^{151}$ Unlike the GCS reports, which cast the central business district as a declining but still regionally competitive shopping district, Gershen Associates tamped down ideas for the commercial use of the Grove, as in the intervening years the retail landscape of Camden and Gloucester Counties had radically changed. Across the country, the rate of retail suburbanization had increased rapidly since the late 1950s, first with freestanding department stores and strip malls and, by the 1960 s, regional shopping malls. ${ }^{152}$ Near Pitman, Delsea Drive south to Glassboro was becoming a retail ribbon by the 1970s. North of Pitman, in Delaware Township, Camden County, the Rouse Company built the Cherry Hill Shopping Center in $1961 .{ }^{153}$ With the largest shopping mall on the eastern seaboard less than an hour's drive away and, with the completion of the Echelon Mall in Voorhees Township, Camden County, in 1969, the prospects

\footnotetext{
${ }^{150}$ Despite their predictions, neither Gershen Associates nor the earlier projections compiled by the Fels Institute GCS staff would prove accurate. By 1980, the population of Pitman was 5 percent less than the Borough's 1970 population, while the borough's estimated 2018 population of 8,780 is well below Gershen and GCS estimates for 1980 - see "Quick Facts, Pitman Borough, New Jersey," United States Census Bureau, accessed June 7, 2020, https://www.census.gov/quickfacts/pitmanboroughnewjersey.

${ }_{151}$ Alvin E. Gershen Associates, The Grove Area: Borough of Pitman, Gloucester County, New Jersey, Final Report. Trenton, NJ, 1971, 4.

${ }^{152}$ By 1973, 15,000 suburban shopping centers and 800 regional malls were built in the United States-Dennis Judd and Robert Mendelson, The Politics of Urban Planning (Urbana: University of Illinois Press, 1973), 69. For the ways federal and state tax policies spurred retail suburbanization, see Tom Hanchett, "The Other 'Subsidized Housing': Federal Aid to Suburbanization, 1940s-1960s," in John Bauman, Roger Biles, and Kristin Szylvian, eds., From Tenements to Taylor Homes: In Search of Urban Housing Policy in Twentieth Century America (University Park: The Pennsylvania State University Press, 2000), 163-179.

${ }^{153}$ The project, later called the Cherry Hill Mall, was designed by Austrian-born architect Victor Gruen, whose projects included the Southdale Mall near Minneapolis, which was the first indoor shopping mall in the United States. For the development of the Cherry Hill Mall, see Stephanie Dyer, "Designing 'Community' in the Cherry Hill Mall: The Social Production of a Consumer Space," Perspectives in Vernacular Architecture 9 (2003): 263-275; Cammarota, 164-166. For Gruen, see M. Jeffery Hardwick, Mall Maker: Victor Gruen, Architect of an American Dream (Philadelphia: University of Pennsylvania Press, 2004).
} 
for Pitman's downtown business district were limited to convenience goods, specialty stores, and professional services. $^{154}$

Instead of expanded retail, Gershen Associates recommended a residential-focused redevelopment. Their project would have three phases: a first phase, turning the western third of the Grove into a seniors housing complex and a municipal parking lot, and two subsequent phases in which the remainder of the Grove's cottages would be replaced with apartment buildings and middle-income townhomes. Finally they recommended the borough establish "a non-profit, or limited profit development corporation" to shepherd the redevelopment and work with federal and state housing authorities for financing. ${ }^{155}$

Council formed Pitman Grove, Inc. (PGI) to serve as the borough's redevelopment agent while Council retained authority over the process. Unlike their previous effort, Council wanted to give sufficient time for planning, determining relocation needs, securing funding, and familiarizing Pitman residents with the plan through public meetings. Time was not, however, redevelopment's friend. By October 1972, Democrats turned redevelopment into a campaign issue. In an election in which Democrats sought to break Republican one-party rule in Pitman, candidates Mildred Tyner and Howard Leroy Davis, a former PURA director, campaigned on a platform to preserve as much of the Grove as possible and turn any efforts at renewal over to private hands. ${ }^{156}$ Although neither of their campaigns were successful that year, by 1974, Council was evenly divided between Democrats and Republicans. Democrats urged the borough to forgive delinquent rents in the Grove and criticized PGI for not being transparent.

\footnotetext{
${ }^{154}$ By 1975, Pitman retailers would face even more serious competition with the completion of the Deptford Mall in Deptford Township. The mall, with 150 stores anchored by Sears, Bamberger's, and Wanamaker's department stores, was a 20-minute drive from Pitman. See Cammarota, 166-167, 208.

155 Gershen Associates, 40.

156 Howard Leroy Davis and Mildred E. Tyner, “Grove Ownership: Public or Private?" The Review (Pitman, NJ), November 1, 1972, 3.
} 
In January 1976, with the political ground shifting beneath his feet, PGI President Theodore Jones, who had been working outside the public eye with planning consultants from the Philadelphia firm of Mullins and Lonergan, and with the Princeton architectural firm of Mahoney \& Zvosec on the design of a seniors complex, held a public meeting to unveil plans for the first phase of redevelopment. The meeting's centerpiece was John Zvosec's architectural renderings of the seniors' complex — a four-story, 200-unit apartment building that Zvosec claimed was not "an architectural masterpiece or a Taj Mahal," but would blend into the "picturesque setting" of the Grove. ${ }^{157}$ Few residents attending the meeting shared Zvosec's enthusiasm. Many were repulsed by a "high-rise tower" in the Grove and balked at the estimated $\$ 29,000$ price tag for a onebedroom apartment in the complex.

After PGI's public meeting, Democrats on Council continued to push to end redevelopment. In March 1976, Davis demanded his colleagues go on record over condemning 26 homes in the Grove whose owners had refused to sell their properties. ${ }^{158}$ Donald Pierpont raised the feasibility of Pitman joining a county housing authority, but, when asked if he thought that decision would end urban renewal, he said: "No. I intend to kill this project much more cleanly."159 Lurking behind Council arguments was another potentially fatal pitfall: tax abatements for developers and a property tax rate increase the borough would need to offset those abatements.

That May, Jones seemed resigned to the collapse of the project. "There's no money for acquisition, relocation-nothing," he told the Courier-Post. ${ }^{160}$ After spending two years on a contingency contract, Mullins and Lonergan's consultant, Robert Totero, had quit, and Zvosec told

\footnotetext{
157 "Residents question Pitman Grove high-rise," Courier-Post, January 30, 1976, 18; "Historic Pitman Grove May Soon Become A Haven for Elderly," Courier-Post, March 25, 1975, 15.

158 “Complex still up in air," Courier-Post, April 27, 1976, 3.

159 Ibid.

${ }^{160}$ Fred Blevins, “Grove a political quagmire,” Courier-Post, May 25, 1976, 13.
} 
Jones that his firm considered the project inactive. "I'm kind of glad, with summer coming along," Jones said. 'I've already taken one vacation, and I'm thinking about others. I'm just going to mull things over for a while and see what develops." In June, Jones faced an extended vacation when the New Jersey Housing Finance Agency moved PGI's application for financing to an "inactive list," and, in response, Council voted to dissolve PGI. ${ }^{161}$ The next month, New Jersey officials intervened in Pitman, declaring Pitman Grove a state historic landmark.

\section{Preservation}

On July 10, 1976, New Jersey Department of Environmental Protection (NJDEP) Commissioner David Bardin added Pitman Grove to the State Register of Historic Sites. ${ }^{162} \mathrm{He}$ also forwarded paperwork to the U.S. Department of the Interior nominating the Grove as a historic district on the National Register of Historic Places. ${ }^{163}$ The listing on the state register meant that the borough would need Bardin's approval before making any changes to the Grove. If the U.S. Department of the Interior accepted the nomination, federal funds would be available to help restore the Grove.

On July 26, 1976, Grove residents once again packed the Council chamber. NJDEP staffer Jonathan Fricker joined the meeting to discuss the implications of the State's actions. ${ }^{164}$ Before

\footnotetext{
${ }^{161}$ Susan Marks, "Pitman Grove Development Disbanded by Town Council," Courier-Post, June 29, 1976, 3.

162 "Pitman Grove is designated a new state historical site," Courier-Post, July 22, 1976, 5.

${ }^{163}$ At the time of the nomination, the State Historic Preservation Officer (SHPO) was a relatively recent addition to the responsibilities of the New Jersey Department of Environmental Protection-responsibilities assumed by Bardin as the DEP Commissioner. The 1966 National Historic Preservation Act not only encouraged states to establish such a position, but also provided grants for historic surveys. The Act also required all federally funded highway, housing, and urban renewal projects to assess their impact on historically significant sites. Although such regulations were established prior to the borough's urban renewal effort, borough authorities may not have been aware of the stipulation as discussion of the Grove's eligibility for national register status was not discussed in either Borough Council minutes or in the minutes of the Planning Board. For general histories of historic preservation in the United States, see Norman Tyler, Ilene Tyler, and Ted Ligibel, Historic Preservation: An introduction to its history, principles, and practice (New York: W. W. Norton, 2000). For histories of the National Historic Preservation Act, see Kimball Banks and Ann Scott, eds., The National Historic Preservation Act: Past, Present, and Future (New York: Routledge, 2016); John Sprinkle, Jr., Crafting Preservation Criteria: The National Register of Historic Places and American Historic Preservation (New York: Routledge, 2014).

${ }^{164}$ Minutes of Borough Council, July 26, 1976.
} 
introducing Fricker, Mayor William Lucas could hardly contain his anger. "There was no cooperation or consideration of the Planning Board or other officials of the borough," Lucas

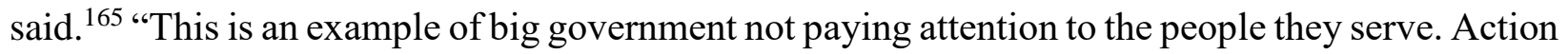
was taken without full and complete consideration of the people. The decision is irreversible with no consideration of the social, economic, and environmental impact." Whether Grove residents found any irony in Lucas's complaint, at least a few people in attendance knew that the NJDEP's action was in response to an effort to save the Grove by cottage owner, local historian, and activist Lorraine Mollenhauer.

"We are on top of the world," Mollenhauer said after the meeting. "It has been an absolutely wonderful day." 166 Mollenhauer, a former member of the Cottagers Association, owned, with her husband, rental cottages in the Grove and had long opposed the borough's urban renewal efforts. She had surreptitiously worked with local history and preservation groups and NJDEP staff to document the Grove's historical significance and prepare the state register nomination paperwork. ${ }^{167}$ The Grove's listings on the State Register and, by August 19, 1977, on the National Register of Historic Places were not, however, panaceas.

Although the borough sold 32 lots to cottage owners in December 1976, the borough would continue to own dozens of cottages and hundreds of empty lots through the end of the twentieth

\footnotetext{
${ }^{165}$ Mary Davis, "Pitman Grove Named to State DEP Historic Site Register," The Review, July 28, 1976, 1. 166 "Pitman Grove is designated a new state historical site," Courier-Post, July 22, 1976, 5.

167 The New Jersey Register of Historic Places Act (N.J.S.A. 13:1B-15. 128 et seq.) passed in 1970, allowed, at the time, citizens to nominate municipal-owned land to the register-neither the approval of nor cooperation by the municipality was technically necessary. Of note, while the preservation of historically significant structures comprised much of the early work of historic preservation in the United States, the preservation of historic districts began as early as 1931, when citizens in Charleston, South Carolina, worked to preserve the Battery neighborhood. Through the late 1950s, the efforts of historically minded citizens and local governments established 12 historic districts across the country. Following the passage of the National Historic Preservation Act, that number increased to more than 120 districts by 1972. See William Murtagh, Keeping Time: The History and Theory of Preservation in America (Hoboken: John Wiley \& Sons, 2006), 87-98.
} 
century. ${ }^{168}$ While some residents took advantage of grant money to renovate their homes, most did not want to become entangled with what they saw as red tape and government control. In February 1976, Council directed a Grove advisory committee to assess the costs of restoring borough-owned cottages. ${ }^{169}$ That fall, the committee recommended that borough authorities apply for federal Housing and Urban Development (HUD) funds. ${ }^{170}$ Over the next ten years, the borough received over \$1 million in restoration grants and low-cost loans for cottage owners through HUD Community Development block grants and funds from the New Jersey Department of Community Affairs.

Despite the infusion of federal and state funds, the Grove's built environment continued to decline, such that by 1983, the Planning Board claimed that "the majority of homes in the Grove [are] in poor condition ... the need for clearance still remains, yet, in some instances, rehabilitation and architectural preservation are viable considerations in conjunction with the Grove's historical site status." ${ }^{171}$ Through the 1980 s, with some federal and state funds in hand and money received from selling several cottages, the borough launched a restoration process of gutting cottage interiors, retaining their historic exteriors, and rebuilding the cottages as energy-efficient structures in line with building codes. ${ }^{172}$ Once renovated, the borough sold the cottages to private buyers with the stipulation that those buyers would live in the cottages for at least six years. The borough rolled the profits back into a fund to restore other cottages.

\footnotetext{
168 “32 Pitman Grove residents get deeds to their homes," Courier-Post, December 14, 1976, 10.

169 "Pitman Plans to Check Cost of Restoration," Courier-Post, August 10, 1976, 12.

${ }^{170}$ Comprehensive Master Plan (1983), 16.

${ }^{171}$ Comprehensive Master Plan, Borough of Pitman, Gloucester County, New Jersey. Borough of Pitman Planning Board, 1983, 17-18.

172 Jayne Feld, "Town-sponsored rehab revives a neighborhood," The Philadelphia Inquirer, March 7, $1993,307$.
} 


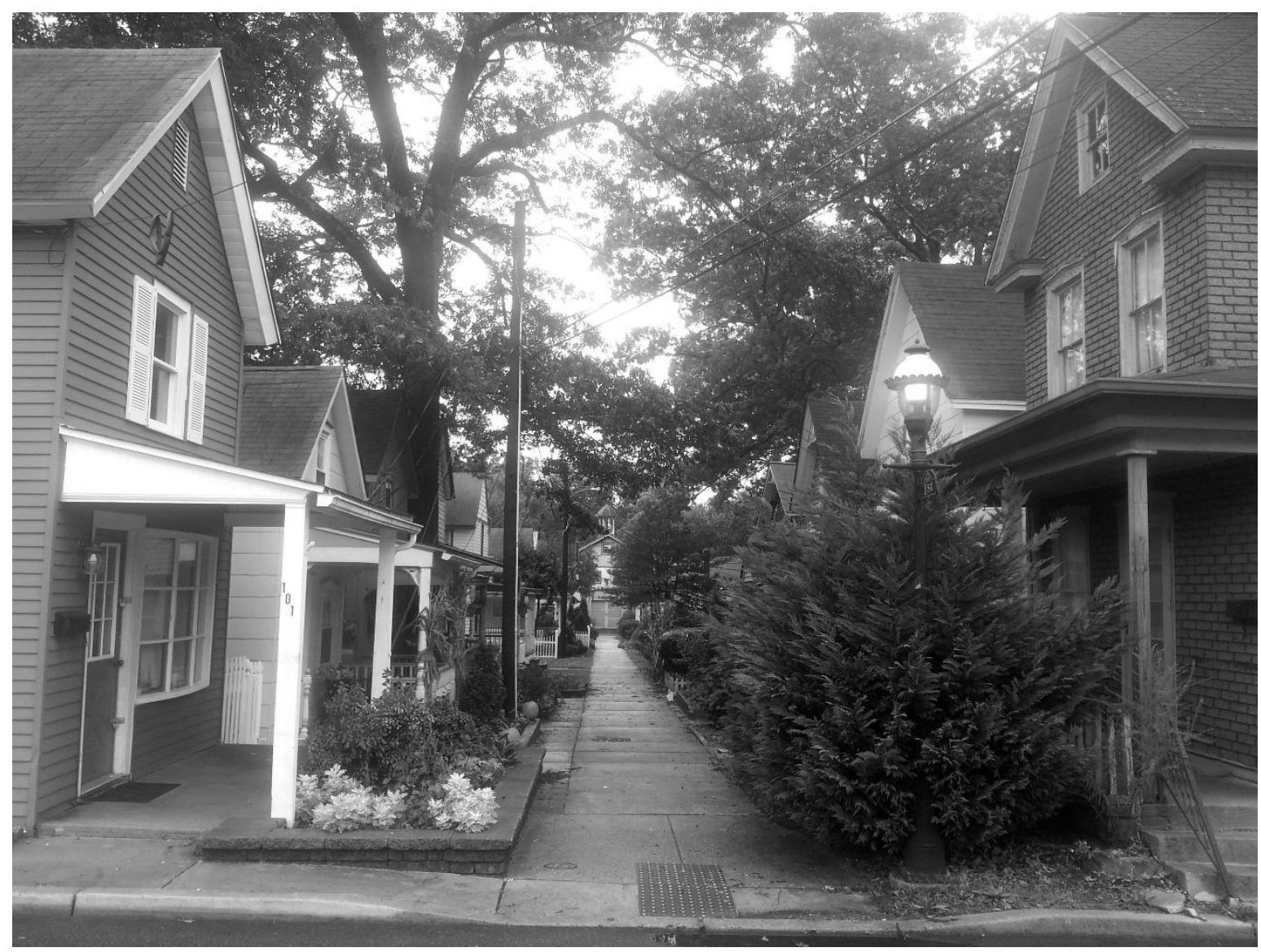

Cottages lining First Avenue, with the recently remodeled Pitman Grove Auditorium in the distance. ${ }^{173}$

In 1986, over some residents' objections, Council declared the Grove, surrounding historic homes, and downtown businesses along Broadway as a historic preservation district. ${ }^{174}$ Council also established the Pitman Historic Preservation Commission, responsible for approving alterations to the exteriors of Grove cottages and the façades of historic downtown businesses. To the degree that historic preservation and national register status spared the Grove from urban renewal, such actions left the Grove squarely in borough authorities' new management regime of restoration and historic zoning restrictions designed to reform the downtown Pitman landscape

\footnotetext{
173 Photo by author (2013).

${ }^{174}$ Robin Kish, "Pitman law for historic area stirs dispute," The Philadelphia Inquirer, June 4, $1986,136$.
} 
and promote economic development. ${ }^{175}$ Through the early 1990s, the borough turned to planning consultants for advice on managing the Grove. In January 1991, after a conclave of planners, architects, and historic preservation consultants met with borough officials and Grove residents, lead planner Alan Mallach of the Princeton planning firm of Mallach, Mostoller, and Travisano presented recommendations for the Grove: sell remaining borough-owned properties either to private owners or, perhaps, establish a nonprofit development corporation to manage the properties, upgrade water and stormwater sewer systems, build architecturally appropriate small houses on vacant lots, form a residents' association, build a senior center and a museum of local history, and renovate the camp meeting auditorium. ${ }^{176}$ For longtime Pitman residents, the recommendations may have sounded as if everything old was new again.

Amid the controversies that shaped the Pitman Grove landscape, South Jersey Methodists have continued to hold revivals at Pitman Grove. Organized by the Pitman United Methodist Church, their crowds have been thin, and the geography of their revivalist network has shrunk to a handful of area churches. However, for a few days every summer, their gatherings are an opportunity to reaffirm the sacrality of the borough-owned auditorium and the surrounding privately owned cottages. ${ }^{177}$ As these Methodists sing hymns and pray for spiritual renewal, they demonstrate the persistence of a religious practice predating South Jersey's suburbanization and the establishment of professional planning in the United States.

\footnotetext{
${ }^{175}$ As Max Page and Randall Mason argue, contrary to the trope of historic preservationists standing as counterweights to local growth machines and an ethos of progress through demolition, historic preservation has a long and complex history of direct links with economic development. Importantly, historic preservation is part of a larger "history industry" of museums, public memorials, documentary television shows, and public history outreach that both promote historical awareness and turn historical sites into marketable assets for communities. See Max Page and Randall Mason, eds., Giving Preservation a History (New York: Routledge, 2004); Harvey Molotch, "The city as a growth machine: Toward a political economy of place," American Journal of Sociology 82, no. 2 (1976); 309-332. ${ }_{176}$ Patricia Quigley, "Groups outline projects for Pitman Grove," The Philadelphia Inquirer, January 6, $1991,230$. 177 "Pitman Grove Camp Meeting," Facebook, accessed May 28, 2020, https://www.facebook.com/PitmanGroveCampMeeting/.
} 
Samuel Avery-Quinn is a University College senior lecturer at Appalachian State University in Boone, North Carolina, where he teaches courses on contemporary American religions and American religious history, landscape, ritual, and sacred architecture. His work in Pitman is tied to two projects: one project traces the twentieth-century history of former Methodist camp meeting communities, while the other project explores the transformation of the South Jersey landscape in the late nineteenth and early twentieth centuries. 